\title{
Fenofibrate in cancer: mechanisms involved in anticancer
}

\section{activity [version 1; peer review: 1 approved with reservations]}

\author{
Tomas Koltai (1D
}

Centro de Diagnostico y Tratamiento de la Obra Social del Personal de la Alimentación, Buenos Aires, 1618, Argentina

V1 First published: 26 Feb 2015, 4:55

https://doi.org/10.12688/f1000research.6153.1

Latest published: $07 \mathrm{Jul} 2015, \mathbf{4 : 5 5}$

https://doi.org/10.12688/f1000research.6153.2

\section{Abstract}

Objective: To review the mechanisms of anti-cancer activity of fenofibrate (FF) and other Peroxisome Proliferator Activator Receptor a (PPARa) agonists based on evidences reported in the published literature.

Methods: We extensively reviewed the literature concerning FF as an off target anti-cancer drug. Controversies regarding conflicting findings were also addressed.

Results: The main mechanism involved in anti-cancer activity is antiangiogenesis through down-regulation of Vascular Endothelial Growth Factor (VEGF), Vascular Endothelial Growth Factor Receptor (VEGFR) and Hypoxia Inducible factor-1 a (HIF-1a), inhibition of endothelial cell migration, up-regulation of endostatin and thrombospondin-1, but there are many other contributing mechanisms like apoptosis and cell cycle arrest, down-regulation of Nuclear Factor Kappa B (NF-kB) and Protein kinase B (Akt) and decrease of cellular energy by impairing mitochondrial function. Growth impairment is related to down-regulation of Phospho-Inositol 3 Kinase (PI3K)/Akt axis and down-regulation of the p38 map kinase (MAPK) cascade. A possible role should be assigned to FF stimulated over-expression of Tribbles Homolog-3 (TRIB3) which inhibits Akt phosphorylation. Important anti-cancer and anti-metastatic activities are due to down-regulation of MCP-1 (monocyte chemotactic protein1), decreased Metalloprotease-9 (MMP-9) production, weak downregulation of adhesion molecules like E selectin, intercellular adhesion molecules (ICAM) and Vascular Endothelial Adhesion Molecules (VCAM), and decreased secretion of chemokines like Interleukin-6 (IL$6)$, and down-regulation of cyclin D-1. There is no direct link between FF activity in lipid metabolism and anticancer activity, except for the fact that many anticancer actions are dependent from PPARa agonism. FF exhibits also PPARa independent anti-cancer activities. Conclusions: There are strong evidences indicating that FF can disrupt growth-related activities in many different cancers, due to anti-angiogenesis and anti-inflammatory effects. Therefore FF may be useful as a complementary adjunct treatment of cancer, particularly included in anti-angiogenic protocols like those currently increasingly

Open Peer Review
Approval Status
version 2
(revision)
07 Jul 2015
26 Feb 2015
1. Krzysz.........................................................
Health Sciences Center, New Orleans, USA
2. Jarosław Czyz, Jagiellonian University,
Krakow, Poland
Any reports and responses or comments on the
article can be found at the end of the article.


used in glioblastoma. There are sound reasons to initiate well planned phase II clinical trials for FF as a complementary adjunct treatment of cancer.

\section{Keywords}

Fenofibrate, cancer, PPAR, angiogenesis, metastasis, prostate, cancer, glioblastoma, melanoma, nelfinavir

\footnotetext{
Corresponding author: Tomas Koltai (tkoltai@hotmail.com)
}

Competing interests: No competing interests were disclosed.

Grant information: The author(s) declared that no grants were involved in supporting this work.

Copyright: @ 2015 Koltai T. This is an open access article distributed under the terms of the Creative Commons Attribution License, which permits unrestricted use, distribution, and reproduction in any medium, provided the original work is properly cited. Data associated with the article are available under the terms of the Creative Commons Zero "No rights reserved" data waiver (CC0 1.0 Public domain dedication).

How to cite this article: Koltai T. Fenofibrate in cancer: mechanisms involved in anticancer activity [version 1; peer review: 1 approved with reservations] F1000Research 2015, 4:55 https://doi.org/10.12688/f1000research.6153.1

First published: 26 Feb 2015, 4:55 https://doi.org/10.12688/f1000research.6153.1 


\section{Abbreviations}

FF: Fenofibrate/HUVEC: Human vascular endothelial cells /MCP-1: Monocyte chemotactic protein-1 /VCAM-1: Vascular cell adhesion molecule 1 /ICAM-1: Intercellular adhesion molecule-1 /VEGF: Vascular endothelial growth factor /VEGFR: Vascular endothelial growth factor receptor /HIF: Hypoxia inducible factor /PPAR: Peroxisome proliferator activator receptor FGF: Fibroblast growth factor /bFGF: basic fibroblast growth factor /TSP-1: Thrombospondin-1 /RXR: Retinoid X receptor /ATRA: All transretinoic acid /ER: Endoplasmic reticulum/RCC: Renal cell carcinoma/PDGF: Platelet derived growth factor/TRIB-3: Tribbles homolog 3 /IGF: Insulin like growth factor/PEG2: Prostaglandin E2 /CTMP: C-terminal modulator protein (which inhibits AKT phosphorylation) /SCC: Squamous cell carcinoma /SREBP: Steroid regulatory element binding proteins /FAS: Fatty acid synthase.

\section{Introduction}

Fenofibrate (FF) is a drug of the fibrate class (a fibric acid derivative) that has been used since 1975 to reduce cholesterol (LDL and VLDL) and triglyceride levels and increase HDL in patients at risk of cardiovascular disease and for treatment of atherosclerosis (1 and 47). FF is one of the most commonly prescribed fibrates, and has a well known efficacy and tolerability profile ${ }^{1}$.

FF seems to lower lipid levels by activating peroxisome proliferatoractivated receptor alpha (PPAR $\alpha)$, a nuclear receptor which acts as a ligand activated transcriptional factor and activates lipoprotein lipase and reducing apolipoprotein CIII expression. These activities increase lipolysis and eliminate triglyceride-rich particles ${ }^{2}$.

PPARs are a widely distributed family of nuclear receptors. Three isoforms have been identified: PPAR $\alpha$, PPAR $\beta / \delta$, and PPAR $\gamma$. Ligand binding activates these receptors that play key roles in cellular energy homeostasis, modulating glucose and lipid metabolism. PPAR $\alpha$ as illustrated in Figure 1, is the molecular target of the fibrate class of drugs, which act as agonistic ligands of PPAR $\alpha$. Other fibrates like clofibrate and bezafibrate are also ligands for this receptor. Poly-unsaturated fatty acids are the natural ligands.

We shall not go any deeper into lipid metabolism activities of FF because our goal is to consider the effects of this pharmaceutical in cancer prevention and treatment rather than in cardiovascular risk.

Before the year 2000, all publications on FF considered anti-lipogenic properties of this drug with no mention of possible anticancer activity.

We only found two publications of FF activities before than that may be related with cancer:

1) Marx et al. (1999) describe that FF reduces the expression of vascular cell adhesion molecule 1 (VCAM-1) in human endothelial cells ${ }^{3}$.

2) Shu et al. (2000) observed that PPAR $\alpha$ or PPAR $\gamma$ reduce secretion of MMP-9 in certain cells (human monocytic THP-1 cells $)^{4}$.

In 2002 two findings on FF anti-cancer therapy were important:

1) It was demonstrated that PPAR $\alpha$ and PPAR $\delta$ downregulate $\mathrm{NF}-\mathrm{kB}$ induced translocation to the nucleus in endothelial cells ${ }^{5}$ and

2) $\operatorname{PPAR} \alpha$ activators inhibited endothelial cell migration by targeting Akt phosphorylation in endothelial cells ${ }^{6}$.

\section{PPRA $\alpha$ activation by ligand binding}

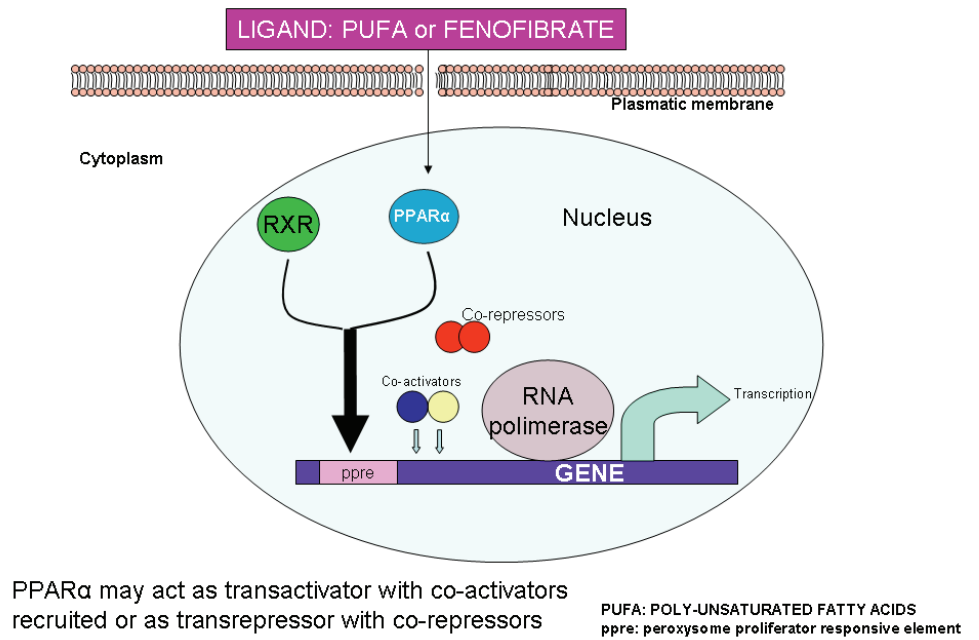

Figure 1. Ligands of PPARa like poly-unsaturated fatty acids or fenofibrate penetrate the cell and meet the receptor in the nucleus. Upon ligand binding, PPAR $\alpha$ dimerizes with RXR (retinoic $X$ receptor) and both interact with peroxisome proliferators responsive elements of the target gene. Coactivator proteins and RNA polymerase are recruited and the transcription machinery is set to work (trans-activation). When co-repressor molecules are recruited, trans-repression is unleashed and no transcription is produced. 


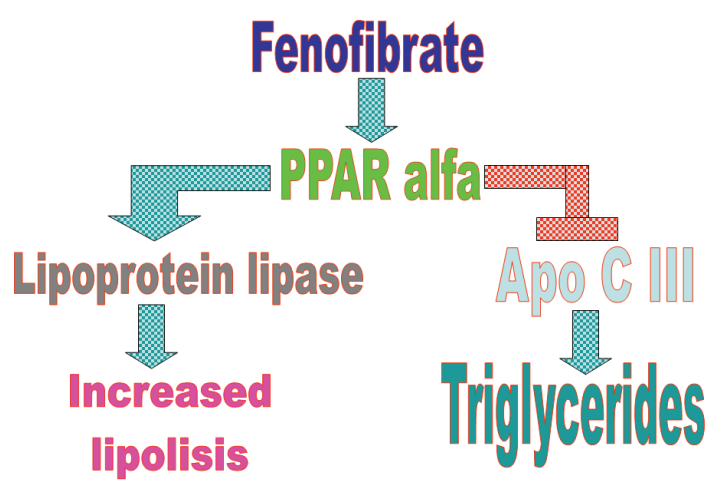

Figure 2. Simplified PPAR $\alpha$ dependent mechanism of action of fenofibrate on lipid metabolism.
FF has the capacity to induce hepatocarcinoma in rodents, but this effect seems specific for this species, as in humans it has been shown to have cytotoxic effect on HepG2 hepatoma cell line at high concentrations and in a dose dependent manner ${ }^{7}$.

Varet et al. $(2003)^{8}$ demonstrated that $\mathrm{FF}$ inhibits angiogenesis in vitro and in vivo.

MCP-1 (monocyte chemotactic protein-1) is a protein that recruits and activates monocytes during inflammatory processes but also plays a role in cancer: it increases proliferation and invasion of $\mathrm{CaP}$ cells (prostate cancer) ${ }^{9}$. FF inhibits expression of MCP-1 on activated endothelial cells ${ }^{10}$.

PPAR $\alpha$ agonists like FF were found to inhibit endothelial VEGFR2 ${ }^{11}$ expression.

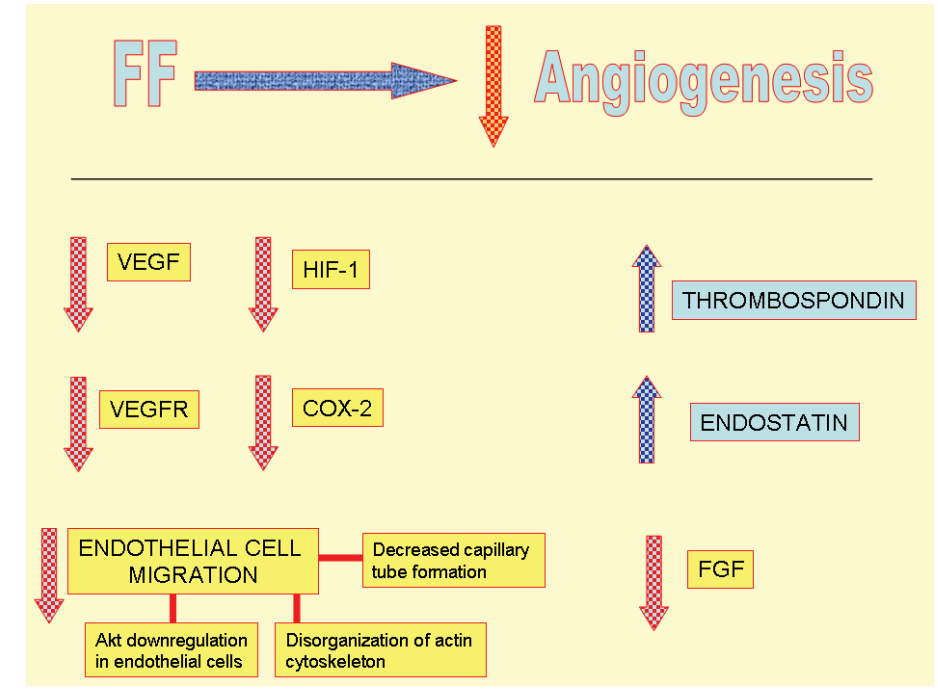

Figure 3. FF anti-angiogenic mechanisms.

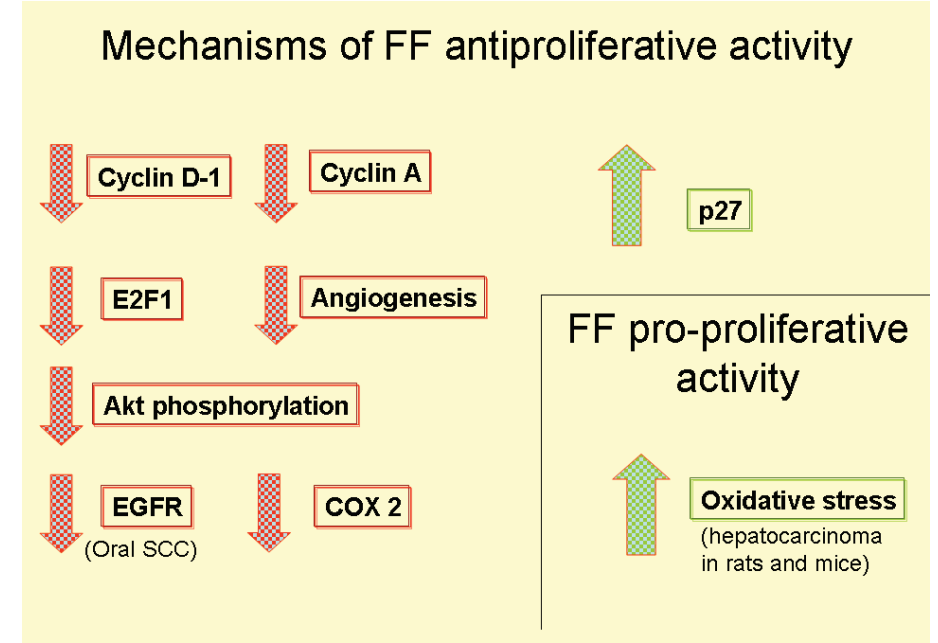

Figure 4. Mechanisms of FF anti-proliferative activity and pro-proliferative activity in mice hepatocarcinoma. 
In diabetic II hyperlipidemic patients, FF decreased E-selectin by $10 \%$ and ICAM- 1 by $4 \%$ and no change of VCAM- 1 was detected $^{12}$.

But the first real hint towards a possible anticancer activity of FF was provided by Holland et al. in $2004^{13}$ who showed by transcriptome analysis of endometrial cancer cells an overexpression of PPAR $\alpha$. This finding led them to the investigation of FF activity on tumor cells. FF reduced proliferation and increased apoptosis of cancer cells. At the same time, a second publication ${ }^{14}$ showed the FF potential to reduce metastasis of melanoma cells in an experimental setting.

In ooforectomized rats, treated with estradiol and FF for 30 days, the uterine mass decreased, uterine glands had normal structure and there were no cases of atypical hyperplasia ${ }^{15}$.

Kubota et al. ${ }^{16}$ found that apoptosis induced by FF in cultured human hepatocytes was due to caspase-dependent apoptosis by inhibiting phosphorylation of Akt, in a PPAR $\alpha$ independent manner.

The role of chemokines produced by different stromal cells stimulating proliferation and angiogenesis in cancer tissues is well known. FF exerts a monocyte suppressing activity and reduces secretion of IL-6 and MCP- ${ }^{17}$.

Studying the possible anti-rheumatic activity of FF it was observed that this compound inhibits NF-kB ${ }^{18}$.

After these preliminary hints indicating the FF possible anti-cancer activities of FF, great amount of research and publications were dedicated to this issue. We summarized these findings in table 1 to table 15 according to anti-cancer activity disclosed.

\section{FF anticancer mechanisms}

On artificial grounds, but for better understanding, we have presented the anti-cancer activity of FF according to the main protumor factor/pathway affected by the drug.
In the field of angiogenesis there is clinical experience with FF besides the laboratory experimental setting. In the research by Blann et al. ${ }^{19}$, hyperlipidemic patients treated with FF showed reduced lipidemia and plasmatic VEGF. No changes in VEGFR levels were seen.

There is a tissue where FF has a pro-angiogenic effect: human retina. An anti-apoptotic property of FF in human retinal endothelial cells was reported by Kim J et al. in $2007^{25}$. FF potently activated AMPactivated protein kinase (AMPK) and vascular endothelial growth factor (VEGF) mRNA expression. This finding was corroborated by the ACCORD medical study ${ }^{26}$ in patients with diabetes type 2 where FF was shown to have protective activity in diabetic retinopaty and other diabetic microvascular complications, probably through a decrease of human retinal endothelial cells apoptosis ${ }^{27}$.

This may mean that FF has a tissue specific activity that needs further investigations.

Probably the strongest and clearest evidence of the FF antiangiogenic activity comes from the research of Panigraphy et al. ${ }^{21}$ of the Judah Folkman team and the research by Dana et al. ${ }^{23}$ on HUVEC.

Angiogenesis inhibition as described in Table 1 is probably one of the main anti-tumor activities of FF. Nickkho-Amiry et al. ${ }^{28}$ showed that treatment of human endometrial cells with a PPAR $\alpha$ agonist leads to reduced secretion of VEGF in addition to reduced proliferation. This was potentiated by $\mathrm{RxR}$ (Retinoid $\mathrm{X}$ receptor) agonist like ATRA and inhibited by a PPAR $\alpha$ antagonist.

In a rat model Onalan et al. showed that FF caused regression of new endometriotic implants due to decreased angiogenesis ${ }^{29}$.

FF was included in many multi-agent anti-angiogenic regimens. One consisted of FF, celecoxib, thalidomide with metronomic low dose cyclophosphamide and etoposide. Patients were less than 21 year old with recurrent or progressive tumors. Half of the patients obtained benefits $(\mathrm{CR}+\mathrm{PR}+\mathrm{SD})^{30}$.

Table 1. Angiogenesis inhibition.

\begin{tabular}{|c|c|}
\hline Reference & FF activities \\
\hline Blann AD, $2001^{19}$ & $\begin{array}{l}\text { The levels of plasma vascular endothelial growth factor and its receptor Flt-1 in patients with hyperlipidemia and } \\
\text { atherosclerosis are lowered by fluvastatin or FF by down-regulation of VEGF and VEGFR. }\end{array}$ \\
\hline Goetze S, $2002^{6}$ & $\begin{array}{l}\text { Both PPAR } \alpha \text { - and PPAR } \gamma \text {-activators inhibited VEGF-induced migration of HUVEC. VEGF-induced Akt } \\
\text { phosphorylation was significantly inhibited by both PPAR } \alpha \text { - and } \gamma \text {-activators. }\end{array}$ \\
\hline Varet J, $2003^{8}$ & $\begin{array}{l}\text { FF inhibits angiogenesis in vitro and in vivo, decreases bFGF induced Akt activation and COX2 expression and } \\
\text { inhibits endothelial cell migration (the latter is attributed to disorganization of the actin skeleton). }\end{array}$ \\
\hline Pozzi A, $2010^{20}$ & $\begin{array}{l}\text { PPAR } \alpha \text { agonists down-regulate angiogenesis by down-regulating epoxyeicosatrienoic acids } \\
\text { synthesis. }\end{array}$ \\
\hline Panigraphy D, $2008^{21}$ & $\begin{array}{l}\text { FF produces many anti-angiogenesis effects and suppresses tumor growth through direct and indirect } \\
\text { angiogenesis inhibition: inhibits endothelial cell proliferation, decreases VEGF, increases TSP-1 and endostatin. }\end{array}$ \\
\hline Zhou J, $2012^{22}$ & $\begin{array}{l}\text { Activation of PPAR } \alpha \text { suppresses hypoxia-inducible factor- } 1 \alpha(\mathrm{HIF}-1 \alpha) \text { signaling in cancer cells. PPAR } \alpha \\
\text { activation promotes HIF- } 1 \alpha \text { degradation in these cells. This was further confirmed using proteasome inhibitors, } \\
\text { which reversed PPAR } \alpha \text {-mediated suppression of HIF-1 } \alpha \text { expression under hypoxia. }\end{array}$ \\
\hline Dana N, $2013^{23}$ & In HUVEC a Matrigel essay showed that FF effectively inhibited angiogenesis. \\
\hline Meissner M, $2004^{24}$ & FF and other PPAR $\alpha$ agonists inhibit VEGFR2 expression in HUVEC. \\
\hline
\end{tabular}




\begin{tabular}{|c|c|}
\hline Reference & FF activity \\
\hline Avis I, $2001^{37}$ & $\begin{array}{l}\text { Exposure of breast cancer cells to a 5-LO inhibitor up-regulated PPAR } \alpha \text { and PPAR expression. Cells } \\
\text { were growth inhibited when exposed to relevant PPAR agonists. }\end{array}$ \\
\hline Chinetti G, $1998^{38}$ & Macrophages activated by TNF $\alpha$ may suffer apoptosis by PPAR $\alpha$ and PPAR $\gamma$ ligands. \\
\hline Holland CM, $2004^{13}$ & $\begin{array}{l}\text { Treatment with FF significantly reduced proliferation and increased cell death in endometrial cancer } \\
\text { cells, suggesting that altered expression of nuclear hormone receptors involved with fatty acid } \\
\text { metabolism leads to deregulated cellular proliferation and apoptosis. PPAR } \alpha \text { was increased more } \\
\text { than 4-folds in endometrial cancer cells. }\end{array}$ \\
\hline Kubota T, $2005^{16}$ & $\begin{array}{l}\text { FF causes caspase-dependent apoptosis in human hepatocytes by inhibiting phosphorylation of Akt, } \\
\text { in which PPAR } \alpha \text { is not involved. (Human hepatocytes) }\end{array}$ \\
\hline Zak Z, $2010^{39}$ & FF induces effective apoptosis in mantle cell lymphoma by inhibiting the TNF $\alpha / N F-k B$ signaling axis. \\
\hline Wang J, $2011^{40}$ & $\begin{array}{l}\text { Combination of FF and cisplatin can enhance the role of cisplatin killing lung cancer A549 cells, which } \\
\text { may be a result of up-regulating caspase-3 and down-regulating survivin. }\end{array}$ \\
\hline Li T, $2014^{41}$ & $\begin{array}{l}\text { FF has anti-proliferation effects on breast cancer cell lines. Apoptosis was independent on the PPAR- } \alpha \\
\text { status with up-regulation of Bad, down-regulation of Bcl-xl, survivin and activation of caspase-3. FF } \\
\text { produced cell cycle arrest at GO/G1 phase with down-regulation of cyclin D1, Cdk4 and up-regulation } \\
\text { of p21, p27/Kip1. In vivo, FF slowed down tumor growth and induced apoptosis in the MDA-MB-231 } \\
\text { xenograft mouse model. }\end{array}$ \\
\hline Binello E, $2014^{42}$ & $\begin{array}{l}\text { FF showed anti-proliferative and pro-apoptotic effects on high-grade gliomas and anti-invasive effects } \\
\text { on glioma stem cells. }\end{array}$ \\
\hline Majeed Y, $2014^{43}$ & $\begin{array}{l}\text { In angiosarcoma forming endothelial cells FF induced apoptosis, reducing Bcl-2, survivin, Akt } \\
\text { expression and Erk proteins. No effects on normal endothelial cells. }\end{array}$ \\
\hline
\end{tabular}

Other metronomic anti-angiogenic multidrug protocols included FF as one of the pharmaceuticals, particularly for children with embryonal brain tumors and other malignancies ${ }^{31-33}$.

The COMBAT Protocol ${ }^{34}$ included low-dose daily temozolomide, etoposide, celecoxib, vitamin D, FF and retinoic acid and was used in 74 children with advanced refractory/relapsed solid tumors with two years overall survival of $43 \%$.

The use of FF as part of anti-angiogenic multidrug protocols especially in pediatric cancer is constantly increasing.

Using a PPAR $\alpha$ agonist like Wy-14643 in mice injected with tumor cells showed that treated animals had a marked reduction in tumor size and vascularization ${ }^{35}$.

In summary: FF increases thrombospondin synthesis, endostatin generation, decreases VEGF, COX2 and VEGFR2 expressions and prevents endothelial cells migration ${ }^{21,36}$.

Apoptosis induced by FF is caspase-dependent. In the case of clofibrate, apoptosis occurs through caspase 2 and 3 activation and ER stress in Jurkat cells ${ }^{44}$. Similar results were observed in Yoshida AH130 hepatoma cells ${ }^{45}$.

PPAR $\alpha$ is increased in high grade renal cell carcinoma (RCC), but this does not provide any information about the functional status of this receptor, because in RCC the inhibition of PPAR $\alpha$ induces apoptosis and agonists produce little or no effect ${ }^{46}$.
In 1983 Pascal et al. ${ }^{47}$ investigated the cardiovascular and antiarteriosclerotic activities of FF and demonstrated that FF inhibited platelet derived growth factor (PDGF) stimulating activity on growth of cultured smooth muscle. Ten years later Munro et al. ${ }^{48}$ showed that FF is not a specific inhibitor of PDGF because smooth muscle cells growth was equally growth-inhibited by FF when the culture was stimulated with fetal calf serum, PDGF or basic fibroblast growth factor (bFGF). Our conclusion based on these two publications is that FF is a growth inhibitor in general (as least regarding vascular smooth muscle).

Anti-proliferation activity of FF has been found in many non-tumor tissues besides vascular smooth muscle, e.g. mesangial cells ${ }^{49}$ through inhibition of PI3K/AKT and ERK1/2 signaling pathways or by overexpression of TRIB3 (tribbles homolog 3) which inhibits Akt phosphorylation and slows cell cycle or causes arrest in $\mathrm{G} 1 / \mathrm{S}^{50}$. In lymphocytes, FF also up-regulates TRIB3 causing cell cycle $\operatorname{arrest}^{51,52}$.

Endothelin-1 is a protein that increases cardiac fibroblast proliferation. PPAR $\alpha$ agonists inhibit cardiac fibroblast proliferation downregulating endothelin- $1^{53}$. FF also reduced c-jun expression in cardiac fibroblasts ${ }^{54}$. Endothelin-1 is an activator of the p38 mitogen activated kinase cascade. FF down-regulation of endothelin-1 also down-regulates the MAPK cascade in cardiomyocites ${ }^{55}$.

FF reduced the IFN $\gamma$ and IL-1 $\beta$-induced cell proliferation of astrocytes in culture ${ }^{56}$. 
Table 3 depicts the anti-proliferation activities of FF in cancer.

The work by Saidi et al. ${ }^{59}$ needs further discussion. The authors noticed that in Ishikawa endometrial cancer cells FF enhanced growth inhibition when ATRA was simultaneously used. ATRA by itself had no effect on growth. This is a logical finding because PPAR $\alpha$ forms a heterodimer with RXR before binding DNA at the peroxisome proliferators responsive element. So this synergy between FF and ATRA regarding growth inhibition seemed a PPAR $\alpha$-dependent activity. Apoptosis also was increased with the combination of these drugs.

Paradoxically, RNAi inhibition of PPAR $\alpha$ showed only a minor reduction in FF effect and ATRA combined with FF showed minor differences in growth inhibition with or without PPAR $\alpha$ RNAi.
After 48 hours of treatment the difference was approximately $40 \%$ less viability in cells treated with FF plus ATRA and no RNAi against those with RNAi. We hypothesize that RNAi inhibition of PPAR $\alpha$ needs at least 48 hours to make the viability difference. So that growth inhibition seems, at least partially, as PPAR $\alpha$ dependent.

They also found down-regulation of two genes: cyclin D1 (CCND1) and methionine adenosyltransferase 2 A (MAT2A), both are progrowth genes ${ }^{59}$. High doses of FF up-regulated p21 (cyclin-dependent kinase inhibitor 1a) and TP53.

Unfortunately FF and FF plus ATRA showed no differences in tumor size and growing in vivo compared with control group receiving no drugs.

\section{Table 3. Anti-proliferation activity of FF.}

\begin{tabular}{|c|c|}
\hline Reference & FF activities \\
\hline Thuillier $P, 2000^{57}$ & Ligands for PPAR $\alpha$ reduce skin cancer by $30 \%$ against skin tumor promotion. \\
\hline Jiao $\mathrm{H}, 2002^{7}$ & $\begin{array}{l}\text { FF inhibits the growth of human HepG2 cells in a dose-related manner and oxidative stress was } \\
\text { involved in this effect. }\end{array}$ \\
\hline Holland CM, $2004^{13}$ & $\begin{array}{l}\text { Treatment with FF significantly reduced proliferation and increased cell death in endometrial cancer } \\
\text { cells. }\end{array}$ \\
\hline Gizard F, $2005^{58}$ & FF inhibits vascular smooth vessel proliferation by inducing anti-oncogen p16. \\
\hline Saidi SA, $2006^{59}$ & $\begin{array}{l}\text { The combination of FF and retinoic acid is a potent inhibitor of Ishikawa endometrial cancer cell } \\
\text { growth in vitro. Cell cycle arrest is produced at G1/S. Cyclin D1 was down-regulated. These results } \\
\text { could not be reproduced in vivo. }\end{array}$ \\
\hline Panigraphy D, $2007^{21}$ & FF suppresses tumor growth through angiogenesis inhibition. \\
\hline Yokoyama Y, $2007^{60}$ & $\begin{array}{l}\text { Clofibric acid (a PPAR } \alpha \text { agonist) significantly suppressed the growth of OVCAR-3 tumors } \\
\text { xenotransplanted s.c. and significantly prolongs the survival of mice with malignant ascites derived } \\
\text { from DISS cells as compared with control. Microvessel density was diminished and apoptosis was } \\
\text { also found. VEGF and PGE2 were also diminished. }\end{array}$ \\
\hline Yamasaki D, $2011^{61}$ & $\begin{array}{l}\text { FF suppresses growth of the human hepatocellular carcinoma cell (Huh7) via PPAR } \alpha \text {-independent } \\
\text { mechanisms and produces G1 arrest caused by the reduction of cyclin A and E2F1 and } \\
\text { accumulation of the cyclin-dependent kinase inhibitor p27. This activity was not modified by PPAR } \alpha \\
\text { antagonists. Inhibition of Akt phosphorylation by increased CTMP was also observed. }\end{array}$ \\
\hline Chang NW, $2011^{62}$ & $\begin{array}{l}\text { FF highly suppresses the formation of squamous cell carcinoma in an oral-specific 4-nitroquinoline } \\
\text { 1-oxide/arecoline mouse model, decreases the tumor size, and increases the immunoreactivity of } \\
\text { EGFR and COX2 in oral dysplasia, but decreases EGFR and COX2 expressions in SCC. These } \\
\text { molecular events might be linked to the EGFR and COX2 regulatory pathways. }\end{array}$ \\
\hline Huang J, $2013^{63}$ & $\begin{array}{l}\text { FF is capable to suppress B-cell lymphoma growth. This growth suppression is independent of } \\
\text { angiogenesis inhibition. }\end{array}$ \\
\hline Binello E, $2014^{42}$ & $\begin{array}{l}\text { FF shows anti-proliferative pro-apoptotic effects on high-grade gliomas and anti-invasive effects on } \\
\text { glioma stem cells. }\end{array}$ \\
\hline Li T, $2014^{41}$ & FF has anti-proliferation effects on breast cancer cell lines. \\
\hline Wang $\mathrm{H}, 2014^{64}$ & $\begin{array}{l}\text { FF can inhibit the growth and migration of human ovarian cancer cell SKOV3 in vitro, and to some } \\
\text { extent induce apoptosis. }\end{array}$ \\
\hline Liang $\mathrm{H}, 2014^{65}$ & $\begin{array}{l}\text { Synergistic inhibitory effects on cancer cell proliferation by simultaneous application of FF and } \\
\text { budesonide. FF inhibited cell proliferation in both TP53 wild type and deficient lung cancer cells. } \\
\text { The anti-proliferation effect of budesonide in TP53 wild type A549 cells was abolished in SK-MES-1 } \\
\text { cells that do not have wild type TP53 protein. }\end{array}$ \\
\hline
\end{tabular}


The work by Chang et al. ${ }^{62}$ suggests that FF may be useful for prevention of oral SCC because in an experimental setting FF was capable of reducing the incidence of tumors and also the progression from pre-neoplastic stage to SCC. FF at low doses lacked antitumor activity.

In spite of the known fact that glucocorticoids induce chemotherapy resistance in most of the solid tumors ${ }^{66}$, Liang et al. ${ }^{65}$ found that FF and budesonide had synergistic anti-proliferative effect on lung cancer cells with intact TP53.

Inflammation plays a very important role in carcinogenesis and tumor progression. NF-kB pathway is an essential actor of the proinflammatory and anti-apoptotic activity ${ }^{67-69}$.

NF-kB pathway increases angiogenesis, proliferation, anti-apoptosis, metastasis and inhibition of differentiation ${ }^{70}$.

FF has the capacity to down-regulate NF-kB activity according to evidences gathered in Table 4. Through this PPAR $\alpha$-dependent mechanism, FF exerts anti-inflammatory activity. Besides, it also has non PPAR $\alpha$-dependent anti-inflammatory activity through upregulation of SHP (small heterodimer partner).

Evidences reported in Table 4 strongly support the FF anti-inflammatory activity mediated through NF-kB down-regulation and also PPAR $\alpha$ independent mechanisms.
One of the proposed mechanisms of FF inhibiting NF-kB activity is depicted in Figure 5.

The research studies reported in Table 5 are evidence of downregulation of Akt phosphorylation by FF, but Piwowarczyk et al. ${ }^{83}$ working with prostate cancer cells (DU-145) and endothelial cells (HUVEC) co-cultures found that FF increased levels of phosphorylated Akt in both HUVEC and DU-145 cells. They found that Akt phosphorylation was essential for FF increase of endothelial barrier (Figure 6).

Mitochondrial uncoupling proteins (UCP) are mitochondrial anion carrier proteins that separate oxidative phosphorylation from ATP synthesis with energy lost as heat and reduction of mitochondrial membrane potential ${ }^{90}$. The main function of UCP2 is the control of mitochondria-derived reactive oxygen species. PPAR $\alpha$ modulates UCP2 expression ${ }^{91}$. Pecker et al. have demonstrated that UCP2 exerts control on proliferation: cells (embryonic fibroblast) where UCP2 expression was down-regulated grew faster than cells expressing UCP2 ${ }^{92}$. They also found that loss of UCP2 produced a metabolic change toward glucose metabolism, decreased fatty acid oxidation and increased proliferation.

Evidence supports that FF decreases intracellular energy through inhibition of mitochondrial enzymes in a similar way as metformin. On a theoretical basis, we may assume that there might be synergism with metformin on this ground.

Table 4. NF-kB down-regulation and ant-inflammatory activity.

\begin{tabular}{|c|c|}
\hline Reference & FF activity \\
\hline Staels B, $1998^{71}$ & $\begin{array}{l}\text { In aortic smooth-muscle cells PPAR } \alpha \text { ligands inhibit IL-1-induced production of IL-6 and } \\
\text { expression of COX -2 as a result of PPAR } \alpha \text { down-regulation of NF-kB signaling. }\end{array}$ \\
\hline Xu X, $2001^{72}$ & $\begin{array}{l}\text { FF and dexamethasone reduced NF-kB binding to its recognition site on the IL-6 promoter. FF } \\
\text { reduced NF-kB binding to the vascular cell adhesion molecule-1 promoter. }\end{array}$ \\
\hline Ogata T, $2004^{73}$ & $\begin{array}{l}\text { FF down-regulates NF-kB in myocardium of DOCA salt rats. IL-6, COX-2, VCAM-1 and MCP-1 } \\
\text { were also down-regulated. }\end{array}$ \\
\hline Okamoto H, $2005^{18}$ & FF inhibits NF-kB signaling in rheumatoid synovial fibroblasts. \\
\hline Yang TL, $2005^{74}$ & FF reduce NF-kB in endothelial cells. This is a PPAR $\alpha$ dependent activity. \\
\hline $\mathrm{Xu} \mathrm{J}, 2006^{75}$ & $\begin{array}{l}\text { FF reduces the signs of inflammation in murine astrocytes and down-regulated pro-inflammatory } \\
\text { cytokines TNF-alpha, IL-1beta, and IL- } 6 \text { by LPS-stimulated astrocytes. FF inhibited NF-kB DNA } \\
\text { binding activity. }\end{array}$ \\
\hline Li L, $2010^{76}$ & $\begin{array}{l}\text { FF attenuates tubulointerstitial fibrosis and inflammation through suppression of NF-kB and } \\
\text { transforming growth factor- } \beta 1 / \text { Smad3 in diabetic nephropathy. }\end{array}$ \\
\hline Zak Z, $2010^{39}$ & $\begin{array}{l}\text { FF induces effective apoptosis in mantle cell lymphoma by inhibiting the TNF } \alpha / N F-k B \text { signaling } \\
\text { axis }\end{array}$ \\
\hline Yang CS, $2013^{77}$ & $\begin{array}{l}\text { FF improved systemic inflammatory responses through the nuclear orphan receptor SHP } \\
\text { (small heterodimer partner) and UCP2 (uncoupling protein 2). This is PPAR } \alpha \text { independent } \\
\text { anti-inflammatory mechanism. }\end{array}$ \\
\hline Schen W, $2014^{78}$ & $\begin{array}{l}\text { FF down-regulated NF-kB in endotoxin induced uveitis. All inflammatory factors like cytokine } \\
\text { production, vessel density, vascular leukostasis and inflammatory cell infiltration was also } \\
\text { down-regulated. }\end{array}$ \\
\hline Binello E, Germano IM, $2014^{79}$ & $\begin{array}{l}\text { FF treatment decreased glioblastoma stem cell invasion in vitro. Treatment decreased the } \\
\text { expression of NF-kB and cyclin D1 in a dose dependent and p53 independent manner. }\end{array}$ \\
\hline
\end{tabular}




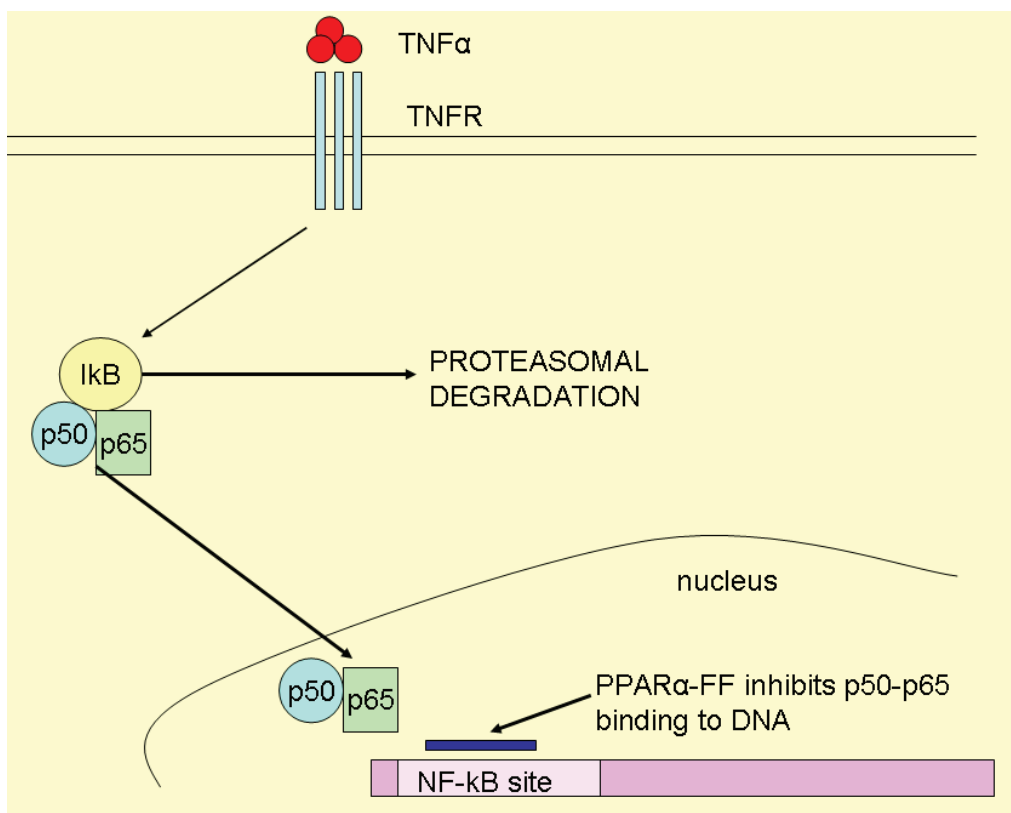

Figure 5. Possible mechanism of NF-kB inhibition by FF.

\begin{tabular}{|c|c|}
\hline Reference & FF activities \\
\hline Goetze S, $2002^{6}$ & PPAR $\alpha$ agonists decrease endothelial cell migration by down-regulating Akt. \\
\hline Kubota T, $2005^{16}$ & FF causes apoptosis in cultured human hepatocytes by inhibiting Akt. \\
\hline Grabacka M, $2006^{80}$ & PPAR $\alpha$ activation decreases metastatic potential of melanoma cells in vitro via down-regulation of Akt. \\
\hline Li R, $2007^{81}$ & $\begin{array}{l}\text { In cardiomyocytes FF and overexpression of PPAR } \alpha \text { inhibited endothelin-1 (ET-1)-induced } \\
\text { phosphorylation of Akt and glycogen synthase kinase } 3 \beta \text { (GSK3 } \beta \text { ). }\end{array}$ \\
\hline Yamasaki D, $2011^{61}$ & $\begin{array}{l}\text { FF suppresses growth of the human hepatocellular carcinoma cell via PPAR } \alpha \text {-independent } \\
\text { mechanisms. It produces G1 arrest caused by the reduction of cyclin A and E2F1 and accumulation } \\
\text { of the cyclin-dependent kinase inhibitor p } 27 \text {. FF also leads to suppression of Akt phosphorylation } \\
\text { by increasing C-terminal modulator protein (CTMP), which inhibits Akt phosphorylation. FF inhibits } \\
\text { proliferation by blocking Akt activation, and CTMP is one of the key players for this effect. }\end{array}$ \\
\hline Majeed Y, 2014 & $\begin{array}{l}\text { In angiosarcoma forming endothelial cells FF induced apoptosis, reducing Bcl-2, survivin, Akt } \\
\text { expression and Erk proteins. No effects on normal endothelial cells were observed. }\end{array}$ \\
\hline Kuno T, $2014^{82}$ & $\begin{array}{l}\text { FF can prevent the development of 4-NQO-induced proliferative lesions in the lung by modulating the } \\
\text { insulin-IGF axis. FF significantly reduced the serum insulin and insulin-like growth factor (IGF)-1 levels, } \\
\text { and decreased the immunohistochemical expression of IGF-1 receptor (IGF-1R), phosphorylated Akt, } \\
\text { and phosphorylated Erk1/2 in lung adenocarcinomas. }\end{array}$ \\
\hline
\end{tabular}

PPAR $\alpha$ involvement with cancer metabolism has been extensively reviewed by Grabacka and Reiss ${ }^{93}$.

Another enzyme down-regulated by FF is FAS (fatty acid synthase $)^{94}$ which is highly expressed in many cancer tissues. Fatty acid synthase (FAS) is a multicomplex enzyme that intervenes in endogenous synthesis of fatty acids and particularly palmitate. Abnormal fatty acid (FA) synthesis is one of the common features of many cancer cells and FAS has been identified as part of cancer controlling networks. Human cancers that over-express FAS, are usually associated with poor prognosis ${ }^{95-99}$.
The expression of adhesion molecules on the endothelial cell surface is critical for cells rolling in the vascular lumen to achieve tethering and adhesion to the vascular wall and eventually achieving diapedesis and colonization in the case of potentially metastatic cells or leukocyte recruitment to atherosclerotic lesions.

PPAR $\alpha$ regulates gene expression of certain adhesion molecules in response to unsaturated fatty acids and fibric acid derivatives like FF. This control is achieved probably through inhibition of TNF $\alpha$ induced NF-kB activation ${ }^{100}$. 


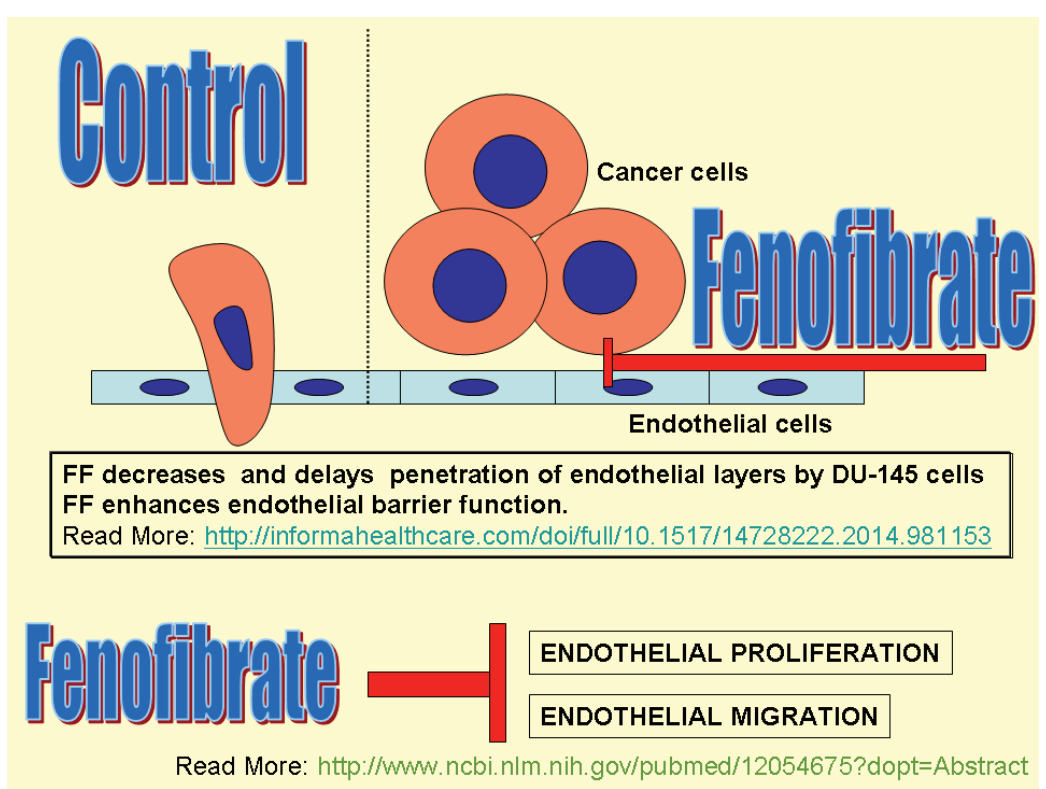

Figure 6. Endothelial barrier enhancement due to FF.

\begin{tabular}{|c|c|}
\hline Reference & FF activity \\
\hline Keller BJ, $1992^{84}$ & Clofibric acid and ciprofibrate inhibited stage 3 oxygen uptake in isolated mitochondria. \\
\hline Zhou Z, $1999^{85}$ & $\begin{array}{l}\text { FF, clofibrate, and ciprofibrate caused a direct dose-dependent depolarization of mitochondrial } \\
\text { membrane potential which produced inhibition of oxidative phosphorylation and inhibition of ATP } \\
\text { synthesis. The authors postulate that these are early events independent of PPAR } \alpha \text { activation. }\end{array}$ \\
\hline Casas F, $2000^{86}$ & $\begin{array}{l}\text { FF or fasting suggests that the two treatments affect mitochondrial activity essentially by stimulating } \\
\text { mitochondrial genome transcription, and increasing cytochrome } \mathrm{c} \text { oxidase activity. }\end{array}$ \\
\hline Brunmair B, $2004^{87}$ & FF impairs rat mitochondrial function by inhibition of respiratory complex I. \\
\hline Nadanaciva S, $2007^{88}$ & FF inhibits mitochondrial complexes I, II+III, and V. \\
\hline Wilk AM, $2012^{89}$ & $\begin{array}{l}\text { In glioblastoma FF is accumulated in the mitochondrial fraction, followed by an immediate } \\
\text { impairment of mitochondrial respiration at the level of complex I of the electron transport chain. This } \\
\text { mitochondrial action sensitizes tested glioblastoma cells to the PPAR } \alpha \text {-dependent metabolic switch } \\
\text { from glycolysis to fatty acid } \beta \text {-oxidation. }\end{array}$ \\
\hline Yang CS, $2013^{77}$ & $\begin{array}{l}\text { FF inhibits systemic inflammatory response through small heterodimer party (SHP) that acts through } \\
\text { mitochondrial uncoupling protein } 2 \text { (UCP-2). }\end{array}$ \\
\hline
\end{tabular}

The research by Marchesi et al. ${ }^{100}$ that demonstrated reduction in adhesion molecules with FF treatment is important for two reasons:

1) It was performed in humans (10 hypertriglyceridemic patients).

2) The amount of reduction in fasting conditions (near $45 \%$ reduction for ICAM and around $33 \%$ reduction for VCAM levels).

Empen et al. (2003) described $10 \%$ reduction of E-selectin after six weeks treatment with FF, but found no major changes with VCAM-1 and ICAM-1 levels ${ }^{12}$.
Piwowarczyc et al. ${ }^{83}$ demonstrated a new FF effect: increased endothelial cell adhesion to the susbstratum and increased adhesion between endothelial cells by activation of focal adhesion kinase (FAK). These impedes cell diapedesis through the vessel wall, which is an important objective to decrease metastatic risk. Figure 6 depicts this activity.

The production of the metastatic cascade is a complex process in which there are many successive steps that we shall not analyze in depth in this review.

But for a better understanding lets remember the main steps ${ }^{107}$ : 
1) Primary tumor growth and angiogenesis.

2) Future metastatic cells free themselves from the primary tumor.

3) These cells degrade surrounding matrix.

4) Reach endothelium of vessels.

5) Enter blood vessels.

6) Circulate and survive in circulation.

7) Reach the target organ.

8) Attach to endothelial cells.

9) Migrate through vessel wall.

10) Start growth in the colonized site including angiogenesis.

11) Produce new metastatic cells.

12) Reinitiate the whole process.

Cell motility, invasion, angiogenesis and the function of connexins and adhesion molecules are an essential part of this cascade and have already been considered. In table 8 we describe only specific research work relative to metastasis and FF.
COX-2 is the rate-limiting enzyme in prostaglandin synthesis that catalyzes the production of prostaglandins and thromboxanes from arachidonic acid, and has been associated with growth regulation and carcinogenesis in many tumors. The COX2/PGE2 pathway may be considered a pro-tumor pathway at least in certain cancers where elevated levels of COX2 have been identified. Most colorectal carcinomas and many adenomas exhibit this elevation ${ }^{109-110}$. One of the postulated mechanisms by which COX2/PGE2 signaling stimulates cell growth is through the activation of $\beta$-catenin ${ }^{111}$. COX2 is implicated in breast cancer progression and invasiveness ${ }^{112,114}$. In stage III breast cancer, COX2 over-expression is an unfavorable prognostic sign, and according to Kim et al. gives ground for using COX2 inhibitor combinations ${ }^{113}$. Simeone et al. identified the pathway leading to increased invasiveness in breast cancer: COX2 /protein kinase C/interleukin-8/urokinase-type plasminogen activator pathway ${ }^{115}$. COX2 is also associated with angiogenesis and metastasis $^{116}$.

Many cancers harbor increased COX2 activity including lung, colorectal, breast and squamous cell carcinoma of the upper digestive system ${ }^{117-119}$. COX2 down-regulation is an important issue in many cancers. We have been describing the action of FF on different pro-tumor proteins in an artificially separate manner, but many of these proteins share their activity in the pro-tumor evolution or are part of the same pathway. This is the case of NF-kB and COX2 in the progression towards cancer of Barret's esophagus in which

\section{Table 7. Anti-adhesion and anti-chemokine activities.}

\begin{tabular}{|c|c|}
\hline Reference & FF activities \\
\hline Marx N, $1999^{3}$ & FF inhibits VCAM-1 transcription probably by inhibiting TNF $\alpha$ induced NF-kB activation. \\
\hline Rival Y, $2002^{5}$ & $\begin{array}{l}\text { Fenofibric acid and FF reduced expression of VCAM- } 1 \text { in endothelial cells and diminished migration of p65 } \\
\text { fraction of NF-kB to the nucleus. }\end{array}$ \\
\hline Marchesi S, 2003 $3^{100}$ & Reduce VCAM and ICAM in hypertriglyceridemic patients. \\
\hline Gervois P, 2004 101 & $\begin{array}{l}\text { Suppression of IL-6-induced acute phase response gene expression after in vivo treatment with FF. } \\
\text { Suppression of IL-6 reduces activation of STAT3 and C-Jun. }\end{array}$ \\
\hline Lefebvre P, $2006^{102}$ & PPAR $\alpha$ inhibits genes induced by NF-kB, such as VCAM-1, COX-2, and IL-6. \\
\hline Ryan KE, $2007^{103}$ & $\begin{array}{l}\text { FF decreased TNF } \alpha \text {, IL- } 6 \text { IL-1 beta VCAM and ICAM in obese glucose tolerant men after } 6 \text { weeks of } \\
\text { treatment. }\end{array}$ \\
\hline Rosenson RS, $2007^{104}$ & $\begin{array}{l}\text { FF lowered fasting and postprandial VCAM }-1(-11 \%) \text { and fasting and postprandial ICAM-1 (-15\%) in patients } \\
\text { with metabolic syndrome and hypertriglyceridemia. }\end{array}$ \\
\hline Lee JW, $2007^{105}$ & $\begin{array}{l}\text { FF repressed IFN- } \gamma \text { and IL- } 17 \text { expression in isolated T cells. FF also repressed the expression of the genes } \\
\text { encoding } 3 \text { chemokines, CXCL10, CCL2, and CCL20, and repressed CXCL10 gene promoter activity in } \\
\text { tumor necrosis factor- } \alpha \text {-treated HT-29 cells. }\end{array}$ \\
\hline Li H, $2007^{106}$ & The E-selectin and ICAM-1 secreting could be inhibited by FF in endothelial cells. \\
\hline Piwowarczyc K, $2014^{83}$ & $\begin{array}{l}\text { FF decreased cancer cell diapedesis by augmenting endothelial cell adhesion to the substratum. This was } \\
\text { accompanied by the activation of ROS signaling, Akt and focal adhesion kinase (FAK) phosphorylation, in } \\
\text { the absence of cytotoxic effects in endothelial cells. }\end{array}$ \\
\hline
\end{tabular}

Table 8. Anti-metastatic activity.

\begin{tabular}{|l|l|}
\hline Reference & FF activities \\
\hline Grabacka M, 2004 & Inhibition of melanoma metastases by FF. \\
\hline Grabacka M, 2006 & $\begin{array}{l}\text { PPAR } \alpha \text { activation decreases migration, colony formation and metastatic potential of Human and mice } \\
\text { melanoma cells in vitro via down-regulation of Akt and ERK } 1 / 2 .\end{array}$ \\
\hline Wybieralska E, 2011 & $\begin{array}{l}\text { Two parameters crucial for cancer cell metastatic potential, i.e. cell motility and gap junctional coupling, are } \\
\text { inhibited by FF in DU 145 prostate cancer cells decreasing invasive potential. }\end{array}$ \\
\hline
\end{tabular}


Table 9. FF as COX2 down-regulator.

\begin{tabular}{|c|c|}
\hline Reference & FF activities \\
\hline Chen XR, $2007^{121}$ & $\begin{array}{l}\text { In a brain damage experimental model performed in rats, Chen et al. demonstrated that FF } \\
\text { improved neurological recovery by anti-inflammatory effects: decrease in iNOS, COX2 and } \\
\text { MMP9 expression. }\end{array}$ \\
\hline Varet J. $2003^{8}$ & Reduced COX2 expression. \\
\hline Ogata T, $2004^{53}$ & $\begin{array}{l}\text { In DOCA salt hypertensive rat model, FF reduced COX } 2 \text { expression, besides decreasing IL-6, } \\
\text { VCAM-1 and MCP-1. }\end{array}$ \\
\hline Chen YJ, $2008^{122}$ & FF reduced COX2 expression in kidney of diabetic rats. \\
\hline Lee DL, $2011^{123}$ & $\begin{array}{l}\text { Similar results as in Ogata T: in a DOCA salt hypertensive rat model FF reduced COX2 and } \\
\text { IL-6 expression. }\end{array}$ \\
\hline Chang NW, $2011^{62}$ & FF reduces COX2 expression in an oral SCC experimental model. \\
\hline Panigraphy D, $2008^{21}$ & Cox 2 was reduced in melanoma B16-F10 cell line when treated with FF. \\
\hline Alvarez de Sotomayor M, $2007^{124}$ & FF decreased COX1 and COX2 in endothelium of resistance arteries in rats. \\
\hline Ramanan S, $2008^{125}$ & $\begin{array}{l}\text { Irradiating a murine microglial cell line with } \gamma \text {-rays led to increased expression of IL-1 } \beta \text { and } \\
\text { TNF } \alpha \text {, Cox2. FF significantly decreased over-expression probably through NF-kB } \\
\text { down-regulation. }\end{array}$ \\
\hline
\end{tabular}

\section{Table 10. Other anti-cancer activities: IGF-1 signaling down-} regulation.

\begin{tabular}{|l|l|}
\hline Reference & FF activities \\
\hline Urbanska K, 2008 & $\begin{array}{l}\text { In medulloblastoma cell lines, FF inhibits } \\
\text { IGF-1 and growth by cell cycle arrest and } \\
\text { induces apoptosis. }\end{array}$ \\
\hline Drukala J, 2010 & $\begin{array}{l}\text { ROS accumulation and IGF-IR inhibition } \\
\text { contribute to FF/PPAR } \alpha \text { mediated } \\
\text { inhibition of glioma cell motility in vitro. }\end{array}$ \\
\hline Kuno T, 201482 & $\begin{array}{l}\text { FF exerts modulation of insulin-IGF-IGFR } \\
\text { axis. }\end{array}$ \\
\hline
\end{tabular}

Table 11. Other anti-cancer activities: anti-hormonal activity.

\begin{tabular}{|l|l|}
\hline Reference & FF activities \\
\hline Toda $\mathrm{K}, 2003^{130}$ & $\begin{array}{l}\text { FF inhibits ovarian estrogen synthesis by } \\
\text { suppressing the aromatase mRNA expression. } \\
\text { Functional PPAR } \alpha \text { is indispensable for the } \\
\text { inhibitory action of the agent in vivo. }\end{array}$ \\
\hline Zhao H, 2013 & $\begin{array}{l}\text { FF down-regulates the expressions of } \\
\text { androgen receptor (AR) and AR target genes } \\
\text { and induces oxidative stress in the prostate } \\
\text { cancer cell line LNCaP. }\end{array}$ \\
\hline
\end{tabular}

Table 12. Other anticancer activities: increased/decreased radiation sensitivity.

\begin{tabular}{|l|l|}
\hline Reference & FF activities \\
\hline Liu Z, 2012 & $\begin{array}{l}\text { FF can reduce radiation sensitivity by ROS } \\
\text { scavenging via SOD induction in HeLa. SOD } \\
\text { induction by FF is related with PPAR } \alpha .\end{array}$ \\
\hline Ge Y, 2014 & $\begin{array}{l}\text { FF enhances radiosensitivity of esophageal } \\
\text { squamous cell carcinoma by suppressing } \\
\text { hypoxia-inducible factor-1 } \alpha \text { expression. }\end{array}$ \\
\hline Liu J, 2014 & $\begin{array}{l}\text { FF enhances radiosensitivity of HNSCC by } \\
\text { inducing arrest and apoptosis. }\end{array}$ \\
\hline
\end{tabular}

Table 13. FF and semaphorin-6B down-regulation.

Established that PPAR $\alpha$ activators (clofibrate) diminished the expression of the human

Collet P, 2004 ${ }^{135}$ SEMA6B gene. Expression of SEMA6B gene in human glioblastoma T98G cells was down-regulated with clofibrate.

Treatments with FF and troglitazone (a PPAR $\gamma$ ligand) strongly decreased the Sema6B

Murad $\mathrm{H}$, 2006 $^{136}$ mRNA. The drop in Sema6B mRNA level and in protein content was more important when the treatment combined the action of FF or troglitazone and 9-cis-retinoic acid.
Table 14. Other miscellaneous anti-cancer activities.

\begin{tabular}{|l|l|}
\hline Reference & FF activities \\
\hline Murakami H, 2006 & $\begin{array}{l}\text { FF activates AMPK and increases eNOS } \\
\text { phosphorylation in HUVEC cells without } \\
\text { transcriptional activity. }\end{array}$ \\
\hline Jiying W, 2012 & $\begin{array}{l}\text { Combined arsenic trioxide and FF } \\
\text { exert a significant effect on } \\
\text { epithelial-mesenchimal transformation } \\
\text { of A549 cells, which may be related with } \\
\text { the expression of E-cadherin and Snail. }\end{array}$ \\
\hline
\end{tabular}

Table 15. Cancer prevention.

\begin{tabular}{|l|l|}
\hline Reference & PPAR $\alpha$ agonists activities \\
\hline Tuillier P, 2000 & $\begin{array}{l}\text { PPAR } \alpha \text { agonists partially prevent } \\
\text { tumor development in skin induced } \\
\text { carcinogenesis. }\end{array}$ \\
\hline Tanaka T, 2001'141 & $\begin{array}{l}\text { PPAR } \alpha \text { agonists prevent abnormal cript } \\
\text { foci in induced colon cancer. }\end{array}$ \\
\hline
\end{tabular}




\begin{tabular}{|c|c|c|}
\hline REFERENCE & TUMOR CELL LINE & SPECIE \\
\hline Panigraphy, $2008^{21}$ & MELANOMA & mice \\
\hline Huang, $2013^{63}$ & MELANOMA & human \\
\hline Grabacka M, $2006^{80}$ & MELANOMA & human and mouse \\
\hline Wilk A, $2015^{89}$ & GLIOBLASTOMA & mouse \\
\hline Han DF, $2015^{159}$ & GLIOBLASTOMA & human \\
\hline Binello E, 2014 & GLIOBLASTOMA & human \\
\hline Wilk A, $2012^{157}$ & GLIOBLASTOMA & human \\
\hline Drukala, $2010^{129}$ & GLIOBLASTOMA & human \\
\hline Urbanska, $2008^{128}$ & MEDULLOBLASTOMA & mouse and human \\
\hline Piwowarczyk, $2015^{83}$ & PROSTATE CARCINOMA & human \\
\hline Zhao H, $2013^{131}$ & PROSTATE CARCINOMA & human \\
\hline Wybieralska E, $2011^{108}$ & PROSTATE CARCINOMA & human \\
\hline Li T, $2014^{41}$ & $\begin{array}{l}\text { BREAST CANCER (triple } \\
\text { negative) }\end{array}$ & human \\
\hline Kuno T, $2014^{82}$ & LUNG CANCER & mice \\
\hline Liang $\mathrm{H}, 2014^{65}$ & LUNG CANCER & human \\
\hline
\end{tabular}

increased NF-kB activity is linked to increased IL-8 and COX2 expression $^{120}$. As described above, FF is active against both: NF-kB and COX2.

The anticancer activities of FF are pleiotropic. Besides proliferation and angiogenesis down-regulation representing the main antitumoral effects, there are many others that will be described in the next three tables like ovarian aromatase inhibition, AMPK activation, IGF-I down-regulation, etc.

The IGF-1 receptor signaling system is a contributing factor in invasion, migration and proliferation of glioblastoma and became a legitimate target in the treatment of this pathology ${ }^{128}$. FF has experimentally shown to inhibit this system and decrease growth and invasion ${ }^{82,126,127}$. A sort of IGF-1 trap was designed by D'Ambrosio et al. ${ }^{129}$ that inhibited tumor growth in vivo and induced apoptosis.

These publications reported contrasting results: two of the showed that FF increased radiation sensitivity ${ }^{133,134}$ and one showed decreased radiation sensitivity ${ }^{132}$. As we shall see latter, PPAR $\alpha$ agonists are tissue-specific and species-specific. This may explain the difference. In the first case the experiments were performed on HeLa cells and in the second and third studies, experiments were performed on squamous cell carcinoma cells. In all three cases human cells were used, so the difference may lay in tissue-specific behavior or may be due to the fact that in the second experiment the environment was particularly hypoxic.

Semaphorins are a large family of axon guidance molecules. They interact with their receptors, plexins and neuropilins, and play important roles in a growing list of diverse biological systems, including cancer progression and tumor angiogenesis. Some semaphorins can activate tumor progression and angiogenesis, while others may have the opposite effect.

There is abundant literature on semaphorins 3,4 and 7. Little is known about semaphorin-6B. It is known that there is an association between gastric cancer ${ }^{137}$, gliobastoma ${ }^{135}$ and certain breast cancers (MCF-7 breast adenocarcinoma cell line ${ }^{136}$ ) and semaphoring-6B but the exact nature of this association is still poorly understood.

PPAR $\alpha$ agonists clofibrate and fenofibrate can down-regulate semaphorin-6B gene expression.

According to $\mathrm{Ge}^{137}$, inhibition of semaphoring-6B expression via RNA interference inhibited the migration, adhesion and invasion abilities of SGC-7901 gastric cancer cells in vitro.

SEMA6B transcript was down-regulated in two human glioblastoma cell lines (T98G and A172) when a prolonged treatment with ATRA was performed ${ }^{138}$.

The SEMA6B gen has a PPAR $\alpha$ binding site in the promoter region so that the interrelation of PPAR $\alpha$ and the gene effectively is present, and this interrelation is a negative one and probably exerts anti-tumoral effects.

In a large population study in Finland to assess the overall risk of prostate cancer in people taking cholesterol lowering medication, no decrease in risk was seen either with statins nor fibrates ${ }^{142}$. The statistics is significantly biased regarding fibrates: the population is too small (around 220 patients with prostate cancer receiving fibrates out of a total number of prostate cancer cases of 24.723). 
HIV treatment with protease inhibitors has a frequent side effect: lipodystrophy syndrome. FF has been very effective in the treatment of this syndrome ${ }^{143}$. Nelfinavir and ritonavir are protease inhibitors which have shown many anti-cancer activities. We have postulated nelfinavir as a complementary off target treatment for cancer ${ }^{144}$. The association of FF with nelfinavir may prevent lipodystrophy, hypertriglyceridemia and elevation of lipoparticules ${ }^{145-147}$. There is no experimental proof of synergy of this interaction regarding cancer treatment, but both drugs share certain characteristics that make synergy a very plausible feature.

Nelfinavir is a proteasome inhibitor, and proteasome is the site where PPAR $\alpha$ is dissembled, so nelfinavir should prolong PPAR $\alpha$ 's life. Moreover nelfinavir and FF share the following activities: Akt inhibition, anti-angiogenesis, decreased proliferation, increased apoptosis, reduction of MMP2 and MMP9, and increased p21 144 .

Table 17 shows similarities and differences between nelfinavir and FF. The main purpose of this table is to illustrate the similarities and differences between this two drugs regarding cancer: nelfinavir down-regulates CDK-2 and FF down-regulates cyclin D-1 reinforcing cell cycle slowdown. Both are strong anti-angiogenic agents. FF also down-regulates COX2 which is an important step in decreasing angiogenesis.

\section{Discussion}

PPAR $\alpha$ is highly expressed in certain cancer cells like endometrium ${ }^{27}$, prostate $^{148}$, bladder ${ }^{149}$, certain breast cancer cell lines ${ }^{150}$, NSCLC $^{152}$ and others.

In these cases, the administration of a PPAR $\alpha$ agonist like FF increased apoptosis and decreased proliferation.

In human breast cancer cell lines MCF-7 and MDA-MB-231, PPAR $\alpha$ was overexpressed but use of agonists of this receptor increased proliferation $^{150}$.

In stark contrast, Li et al. ${ }^{152}$ tested FF in 12 breast cancer cell lines (including MDA-MB-231) and in all of them FF was effective as proliferation inhibitor. This effectiveness was independent of PPAR $\alpha$ expression but was linked to triple negative condition. Paradoxically MDA-MB-231 was the more sensitive to inhibition of proliferation by FF treatment.

Table 17. Similarities and differences between nelfinavir and FF.

\begin{tabular}{|c|c|c|}
\hline & NELFINAVIR & FENOFIBRATE \\
\hline NF-kB & Down-regulates & Down-regulates \\
\hline MMP-2 and 9 & Down-regulates & Down-regulates \\
\hline CDK-2 & Down-regulates & \\
\hline Cyclin D-1 & & Down-regulates \\
\hline VEGF & Down-regulates & Down-regulates \\
\hline HIF-1 & Down-regulates & Down-regulates \\
\hline bFGF & Down-regulates & Down-regulates \\
\hline cox-2 & & Down-regulates \\
\hline FAS & Down-regulates & Down-regulates \\
\hline AKT inhibition & Strong inhibitor & Inhibitor in certain tissues \\
\hline AMPK & & Activator \\
\hline Radiosensitivity & Increases & Increases \\
\hline ER stressor & Stressor & \\
\hline Growth & Slows down & Slows down \\
\hline Angiogenesis & Decreases & Decreases \\
\hline Invasion & Decreases & Decreases \\
\hline nSREBP-1 & Inhibits & Does not inhibit \\
\hline SREBP-2 & & Inhibitor \\
\hline Apoptosis & Increases & Increases \\
\hline $\begin{array}{l}\text { Breast cancer } \\
\text { resistance protein }\end{array}$ & Inhibits & \\
\hline $\begin{array}{l}\text { ATP mitochondrial } \\
\text { production }\end{array}$ & Decreases & Decreases \\
\hline Adhesion molecules & & Down-regulates \\
\hline Lipodistrophy & Produces lypodistrophy & Prevents lipodistrophy \\
\hline Triglycerides & Increases & Decreases \\
\hline Androgen receptor & Down-regulates & Down-regulates \\
\hline
\end{tabular}

Note: Blank cells mean that the activity has not been checked or has not been published. 
In human colon cancer tissues PPAR $\alpha$ is underexpressed when compared with normal tissues ${ }^{151}$. Using PPAR $\alpha$ ligands in $\mathrm{APC}^{\mathrm{Min}} /+$ mice to evaluate polyp formation, those treated showed decreased number of polyps and decreased size. We may conclude that overexpression or under-expression of PPAR $\alpha$ in cancer tissues is not an indicator of future response to FF or other PPAR $\alpha$ agonists.

Another issue to consider is the species-specific response to PPAR $\alpha$ agonists: for instance, FF induces hepatocarcinogenesis in rodents but not in humans, insulin resistance in mouse but not in humans, oxidative stress in mouse heart but not in human heart. Human liver has a lower expression of PPAR $\alpha$ than rodents ${ }^{153}$ (The differences of PPAR $\alpha$ in human liver has been extensively described in the review by Roberts ${ }^{154}$ ).

There are important differences between rat and human hepatic cells. Vanden Heuvel et al. ${ }^{155}$ studied the gene expression differences between rat hepatoma cells $(\mathrm{FaO})$ and human hepatocarcinoma cells (HepG2) when treated with a PPAR $\alpha$ agonist like WY14643. A large number of kinases and phosphatases were affected in $\mathrm{FaO}$ and not in HepG2 cells. Many of them were implicated in cell cycle control and growth signaling like JAK1, JAK2, GSK3 $\alpha$ and MKP-1.

Rat peroxisomes contain urate oxidase which is absent in human peroxisomes $^{156}$.

Acyl Co A oxidase (ACO) is a key enzyme in peroxisomes and according to Roberts et al. ${ }^{154}$ there are differences between human and rat ACO: the promoter for human $\mathrm{ACO}$ has a different sequence and activity from rats ACO.

PPAR $\alpha$ agonists like FF are tissue-specific. They may increase VEGF and angiogenesis in retina ${ }^{22,23}$ and the opposite in tumor cells ${ }^{20,21}$.

Thus this species- and tissue-specificity suggests that we should be cautious when interpreting the results of many of the published investigations. PPAR $\alpha$ agonists research results obtained in rodents should not be taken for granted in humans.

The mechanism of FF anticancer activity may differ in different tumors: in mantle cell lymphoma it seems to induce apoptosis by inhibiting the TNFo/NF-kB axis ${ }^{39}$ while in triple negative breast cancer it requires activation of NF-kB in order to induce apoptosis ${ }^{41}$.

PPAR $\alpha$ agonists like FF are actively investigated as anti-cancer drugs, but paradoxically, PPAR $\alpha$ inhibitors may also work against cancer. This is the case of renal cell carcinoma ${ }^{46}$ where an inhibitor of this receptor produced cell cycle arrest and apoptosis.

After these necessary clarifying precautions, we must consider in detail the hard evidence collected in the medical literature that gives ground for FF as a complementary adjunct pharmaceutical in cancer therapy.

Phanigraphy et al. ${ }^{21}$ tested 19 human tumor cell lines in vitro and found that all expressed PPAR $\alpha$ in tumor cells and endothelium. There were differences regarding levels of PPAR $\alpha$. Fibrates and particularly FF at clinically achievable concentrations showed capacity to inhibit proliferation in these cell lines that included highly malignant ones like melanoma and Lewis lung carcinoma cell lines. FF inhibited $95 \%$ of bovine capillary endothelial cells proliferation and migration. There was no inhibition on normal fibroblasts growth. In glioblastoma cells FF reduced VEGF secretion by $50 \%$ and increased TSP- 1 expression by 3 - to 4 - fold in a fibrosarcoma cell line. The results of these experiments show that FF exerts anti-proliferative and anti-angiogenic activities in tumor cells in vitro at clinically achievable concentrations. Similar results were observed in subcutaneously implanted tumors in mice. The seminal work of Panigraphy et al. concludes that anti-proliferative and anti-angiogenic properties of FF are PPAR $\alpha$ activation dependent.

Glioblastoma treatment has already introduced FF as part of different anti-angiogenic schedules, but FF may have also other anti-tumoral effects in this disease besides anti-angiogenesis, particularly apoptosis ${ }^{157-159}$

Endometrial carcinoma usually overexpresses PPAR $\alpha$. When PPAR $\alpha$ expression is reduced with siRNA in vitro, cellular proliferation decreased substantially and showed a small increase in apoptosis in Ishikawa cells and HEC-1A cells ${ }^{28}$. Both cell lines reduced VEGF levels when they were treated with FF. Reduction in VEGF after FF treatment showed differences between the two cell lines: HEC-1A showed potentiation of inhibition of VEGF when an RXR ligand was added; Ishikawa cells did not. This reinforces the concept that there may appear important differences with FF treatment according to the tumor type.

FF also uses the AMPK pathway to produce its anti-tumoral effects $^{160}$. This is a PPAR $\alpha$ independent action that has been demonstrated in human oral squamous cell carcinoma (OSCC) where FF inhibited cell migration and invasion and reduced expression of MMP 1, 2, 7 and 9. LKB1 and AMPK were up-regulated after FF treatment. When AMPK was inhibited (with protein $\mathrm{C}$ ) the antiinvasive effect was significantly reduced.

Metformin is another activator of the AMPK pathway. It has not been tested with FF but it is quite possible that there might be synergy in this activity. Another coincidence between metformin and FF is the decrease in cellular energy production.

The molecular mechanism of many of the FF anti-cancer activities is known since $2006^{161}$ and can be summarized as inhibition of COX2 and VEGF at the transcription level by interfering with AP-1 binding to DNA and decreased expression of NF-kB. In susceptible cells there is a negative cross talk between PPAR $\alpha$ and AP- $1^{161}$.

Another mechanism postulated in anti-cancer activity is the disruption of the tumor-host stroma symbiosis due to anti-angiogenesis and anti-inflammatory activity ${ }^{162}$.

Finally we have to mention that FF effectively reduces nuclear SREBP-2 but not SREBP-1 ${ }^{163-166}$. Nelfinavir and PUFA inhibit mature SREB-1 which is a transcription factor that promotes FAS synthesis, so these products may complement FF anti-cancer activity. 


\section{Conclusion}

As observed in the tables, FF exerts polyvalent anti-cancer activities that deserve further research in the clinical setting.

FF is a PPAR $\alpha$ agonist drug developed for treatment of elevated triglycerides and LDL cholesterol reducing cardiovascular risk that may be repurposed to be used in cancer due to its anti-angiogenic, anti-inflammatory, anti-proliferative, anti-metastatic, anti-adhesive, anti-invasive and pro-apoptotic activities in certain cancers.

\section{Future perspectives}

FF has already been incorporated in anti-angiogenic protocols for the treatment of glioblastoma. Probably in the future it will form part of protocols based on repurposed drugs directed to inhibit angiogenenesis like celecoxib, nelfinavir, and metformin.

Colorectal and prostate cancer seem good candidates for these therapies.

\section{Competing interests}

No competing interests were disclosed.

\section{Grant information}

The author(s) declared that no grants were involved in supporting this work.
1. Yang LP, Keating GM: Fenofibric acid: in Combination therapy in the treatment of mixed dsylipidemia. Am J Cardiovasc Drugs. 2009; 9(6): 401-409. PubMed Abstract | Publisher Full Text

2. Staels B, Vu-Dac N, Kosykh VA, et al.: Fibrates downregulate apolipoprotein C-III expression independent of induction of peroxisomal acyl coenzyme A oxidase. A potential mechanism for the hypolipidemic action of fibrates. J Clin Invest. 1995; 95(2): 705-12. PubMed Abstract | Publisher Full Text | Free Full Text

3. Marx N, Sukhova GK, Collins T, et al:: PPARalpha activators inhibit cytokineinduced vascular cell adhesion molecule-1 expression in human endothelial cells. Circulation. 1999; 99(24): 3125-3131.

PubMed Abstract | Publisher Full Text | Free Full Text

4. Shu $\mathrm{H}$, Wong B, Zhou G, et al:: Activation of PPARalpha or gamma reduces secretion of matrix metalloproteinase 9 but not interleukin 8 from human monocytic THP-1 cells. Biochem Biophys Commun. 2000; 267(1): 345-349. PubMed Abstract | Publisher Full Text

5. Rival Y, Benéteau N, Taillandier T, et al.: PPARalpha and PPARdelta activators inhibit cytokine-induced nuclear translocation of NF-kappaB and expression of VCAM-1 in EAhy926 endothelial cells. Eur J Pharmacol. 2002; 435(2-3): 143-51.

PubMed Abstract | Publisher Full Text

6. Goetze S, Eilers F, Bungenstock A, et al.: PPAR activators inhibit endothelial cell migration by targeting Akt. Biochem Biophys Res Commun. 2002; 293(5): $1431-7$.

PubMed Abstract | Publisher Full Text

7. Jiao HL, Zhao BL: Cytotoxic effect of peroxisome proliferator fenofibrate on human HepG2 hepatoma cell line and relevant mechanisms. Toxicol Appl Pharmacol. 2002; 185(3): 172-9.

PubMed Abstract | Publisher Full Text

8. Varet $\mathrm{J}$, Vincent $\mathrm{L}$, Mirshahi $\mathrm{P}$, et al:: Fenofibrate inhibits angiogenesis in vitro and in vivo. Cell Mol Life Sci. 2003; 60(4): 810-9.

PubMed Abstract | Publisher Full Text

9. Lu Y, Cai Z, Galson DL, et al:: Monocyte chemotactic protein-1 (MCP-1) acts as a paracrine and autocrine factor for prostate cancer growth and invasion. Prostate. 2006; 66(12): 1311-1388. PubMed Abstract | Publisher Full Text

10. Sonoki K, Iwase M, lino K, et al:: Dilazep and fenofibric acid inhibit MCP-1 mRNA expression in glycoxidized LDL-stimulated human endothelial cells. Eur J Pharmacol. 2003; 475(1-3): 139-147. PubMed Abstract | Publisher Full Text

11. Meissner $M$, Stein $M$, Urbich $C$, et al:: PPARalpha activators inhibit vascula endothelial growth factor receptor-2 expression by repressing $\mathrm{Sp} 1$ dependent DNA binding and transactivation. Circ Res. 2004; 94(3): 324-332. PubMed Abstract | Publisher Full Text

12. Empen K, Frost RJ, Geiss HC, et al: Differential effects of fenofibrate versus atorvastatin on the concentrations of E-selectin and vascular cellular adhesion molecule- 1 in patients with type 2 diabetes mellitus and mixed hyperlipoproteinemia: a randomized cross-over trial. Cardiovascular Diabetology. 2003; 2: 17

PubMed Abstract | Publisher Full Text | Free Full Text

13. Holland CM, Saidi SA, Evans AL, et al.: Transcriptome analysis of endometria cancer identifies peroxisome proliferator-activated receptors as potential therapeutic targets. Mol Cancer Ther. 2004; 3(8): 993-1001. PubMed Abstract
14. Grabacka M, Placha W, Plonka PM, et al.: Inhibition of melanoma metastases by fenofibrate. Arch Dermatol Res. 2004; 296(2): 54-8.

PubMed Abstract | Publisher Full Text

15. Gunin AG, Bitter AD, Demakov AB, et al.: Effects of peroxisome proliferato activated receptors-alpha and -gamma agonists on estradiol-induced proliferation and hyperplasia formation in the mouse uterus. $J$ Endocrinol. 2004; 182(2): 229-39.

PubMed Abstract | Publisher Full Text

16. Kubota T, Yano T, Fujisaki K, et al.: Fenofibrate induces apoptotic injury in cultured human hepatocytes by inhibiting phosphorylation of Akt. Apoptosis. 2005; 10(2): 349-358.

PubMed Abstract | Publisher Full Text

17. Okopień B, Kowalski J, Krysiak R, et al:: Monocyte suppressing action of fenofibrate. Pharmacol Rep. 2005; 57(3): 367-72. PubMed Abstract

18. Okamoto $\mathrm{H}$, Iwamoto $\mathrm{T}$, Kotake $\mathrm{S}$, et al.: Inhibition of NF-kappaB signaling by fenofibrate, a peroxisome proliferator-activated receptor-alpha ligand, presents a therapeutic strategy for rheumatoid arthritis. Clin Exp Rheumatol. 2005; 23(3): 323-30. PubMed Abstract

19. Blann AD, Belgore FM, Constans J, et al.: Plasma vascular endothelial growth factor and its receptor Flt-1 in patients with hyperlipidemia and atherosclerosis and the effects of fluvastatin or fenofibrate. Am J Cardiol. 2001; 87(10): $1160-1163$ 87(10): 1160-1163.
PubMed Abstract | Publisher Full Text

20. Pozzi A, Popescu V, Yang S, et al: The anti-tumorigenic properties of peroxisomal proliferator-activated receptor alpha are arachidonic acid epoxygenase-mediated. J Biol Chem. 2010; 285(17): 12840-12850. PubMed Abstract | Publisher Full Text | Free Full Text

21. Panigraphy D, Kaipainen A, Huang S, et al:: PPARalpha agonist fenofibrate suppresses tumor growth through direct and indirect angiogenesis inhibition. Proc Natl Acad Sci U S A. 2008; 105(3): 985-990. PubMed Abstract | Publisher Full Text | Free Full Text

22. Zhou J, Zhang S, Xue J, et al: Activation of peroxisome proliferator-activated receptor $\alpha$ (PPAR $\alpha$ ) suppresses hypoxia inducible factor-1 $\alpha$ (HIF-1 $\alpha$ ) signaling in cancer cells. J Biol Chem. 2012; 287(42): 35161-35169. PubMed Abstract | Publisher Full Text | Free Full Text

23. Dana N, Javanmard SH, Fazilati M, et al:: A comparison of peroxisome proliferator-activated receptor- $\alpha$ agonist and antagonist on human umbilical vein endothelial cells angiogenesis. Adv Biomed Res. 2013; 2(1): 54. PubMed Abstract | Publisher Full Text | Free Full Text

24. Meisnner M, Stein M, Urbich C, et al:: PPARalpha Activators Inhibit Vascular Endothelial Growth Factor Receptor-2 Expression by Repressing Sp1 Dependent DNA Binding and Transactivation. Circ Res. 2004; 94(3): 324-332. PubMed Abstract | Publisher Full Text

25. Kim J, Ahn JH, Kim JH, et al.: Fenofibrate regulates retinal endothelial cell survival through the AMPK signal transduction pathway. Exp Eye Res. 2007; 84(5): 886-893.

PubMled Abstract | Publisher Full Text

26. Chew EY, Ambrosius WT, Davis MD, et al:: Effects of medical therapies on retinopathy progression in type 2 diabetes. N Engl J Med. 2010; 363(3): 233-244.

PubMed Abstract | Publisher Full Text | Free Full Text 
27. Noonan JE, Jenkins AJ, Ma JX, et al.: An update on the molecular actions of Fenofibrate and its clinical effects on diabetic retinopathy and other microvascular end points in patients with diabetes. Diabetes. 2013; 62(12): 3968-3975.

PubMed Abstract | Publisher Full Text | Free Full Text

28. Nickkho-Amiry M, McVey R, Holland C: Peroxisome Proliferator-Activated Receptors Modulate Proliferation and Angiogenesis in Human Endometrial Carcinoma. Mol Cancer Res. 2012; 10(3): 441-453.

PubMed Abstract | Publisher Full Text

29. Onalan G, Zeyneloglu HB, Bayraktar N: Fenofibrate causes regression of endometriotic implants: a rat model. Fertil Steril. 2009; 92(6): 2100-2102. PubMed Abstract | Publisher Full Text

30. Robison NJ, Campigotto F, Chi SN, et al:: A phase II trial of a multi-agent oral antiangiogenic (metronomic) regimen in children with recurrent or progressive cancer. Pediatr Blood Cancer. 2014; 61(4): 636-642.

PubMed Abstract | Publisher Full Text | Free Full Text

31. Peyrl A, Chocholous M, Kieran MW, et al:: Antiangiogenic metronomic therapy for children with recurrent embryonal brain tumors. Pediatr Blood Cancer. 2012; 59(3): 511-517.

PubMed Abstract | Publisher Full Text

32. Peyrl A, Chocholous M, Kieran MW, et al.: Metronomic antiangiogenic therapy in children with recurrent brain tumours of different histologies. Magazine of European Medical Oncology. 2011; 4(3): 21-23.

Publisher Full Text

33. Sterba J, Pavelka Z, Andre N, et al: Second complete remission of relapsed medulloblastoma induced by metronomic chemotherapy. Pediatr Blood Cancer. 2010; 54(4): 616-617.

PubMed Abstract | Publisher Full Text

34. Zapletalova D, André N, Deak L, et al:: Metronomic Chemotherapy with the COMBAT Regimen in Advanced Pediatric Malignancies: A Multicenter

Experience. Oncology. 2012; 82(5): 249-260.

PubMed Abstract | Publisher Full Text

35. Pozzi A, Ibanez MR, Gatica AE, et al.: Peroxisomal proliferator-activated receptor-alpha-dependent inhibition of endothelial cell proliferation and tumorigenesis. J Biol Chem. 2007; 282(24): 17685-17695.

PubMed Abstract | Publisher Full Text

36. Pozzi A, Capdevila JH: PPARalpha ligands as antitumorigenic and antiangiogenic agents. PPAR Res. 2008; 2008: 906542. PubMed Abstract | Publisher Full Text | Free Full Text

37. Avis I, Hong SH, Martinez A, et al:: Five-lipoxygenase inhibitors can mediate apoptosis in human breast cancer cell lines through complex eicosanoid interactions. FASEB J. 2001; 15(11): 2007-9.

PubMed Abstract | Publisher Full Text

38. Chinetti G, Griglio S, Antonucci M, et al:: Activation of Proliferator-activated Receptors alpha and gamma Induces Apoptosis of Human Monocyte-derived Macrophages. J Biol Chem. 1998; 273(40): 25573-25580.

PubMed Abstract | Publisher Full Text

39. Zak Z, Gelebart P, Lai RR: Fenofibrate induces effective apoptosis in mantle cell lymphoma by inhibiting the TNFalpha/NF-kappaB signaling axis. Leukemia. 2010; 24(8): 1476-1486.

PubMed Abstract | Publisher Full Text

40. Wang J, Wang $\mathrm{T}$, Zeng $\mathrm{J}$, et al:: Experimental study of fenofibrate combined with cisplatin on inhibition and apoptosis of human lung cancer A549 cell line. Shandong Medical Journal. 2011; 48.

Reference Source

41. Li T, Zhang Q, Zhang J, et al:: Fenofibrate induces apoptosis of triple-negative breast cancer cells via activation of NF-KB pathway. BMC Cancer. 2014; 14: 96. PubMed Abstract | Publisher Full Text | Free Full Text

42. Binello E, Mormone E, Emdad L, et al.: Characterization of fenofibrate-mediated anti-proliferative pro-apoptotic effects on high-grade gliomas and anti-invasive effects on glioma stem cells. J Neurooncol. 2014; 117(2): 225-234. PubMed Abstract | Publisher Full Text

43. Majeed $\mathrm{Y}, \mathrm{Taba} \mathrm{T}$, Shaheen $\mathrm{Y}$ : Molecular basis of the anti-proliferative action of the hypolipidemic drug fenofibrate in vitro in angiosarcoma-forming endothelial cells. Qatar Foundation Annual Research Conference Proceedings Volume 1 HBPP0064. 2014.

Reference Source

44. Penna F, Pin F, Costamagna D, et al.: Caspase 2 Activation and ER Stress Drive Rapid Jurkat Cell Apoptosis by Clofibrate. PLoS One. 2012; 7(9): e45327. PubMed Abstract | Publisher Full Text | Free Full Text

45. Penna F, Reffo P, Muzio G, et al:: Mechanisms of clofibrate-induced apoptosis in Yoshida AH-130 hepatoma cells. Biochem Pharmacol. 2009; 77(2): 169-176.

PubMed Abstract | Publisher Full Text

46. Abu Aboud O, Wettersten HI, Weiss RH: Inhibition of PPAR $\alpha$ Induces Cell Cycle Arrest and Apoptosis, and Synergizes with Glycolysis Inhibition in Kidney Cancer Cells. PLoS One. 2013; 8(8): e71115. PubMed Abstract | Publisher Full Text | Free Full Text

47. Pascal M, Sepulchre C, Chazan JB, et al:: Evidence for the inhibition of plateletderived growth factor induced rat smooth muscle cells DNA synthesis by fenofibric acid at the Go/G1 cell cycle level. Life Sci. 1983; 33(10): 925-33. PubMed Abstract | Publisher Full Text
48. Munro E, Patel M, Chan P, et al.: Growth inhibition of human vascular smooth muscle cells by fenofibrate: a possible therapy for restenosis. Cardiovasc Res. 1994; 28(5): 615-20.

PubMed Abstract | Publisher Full Text

49. Zeng R, Xiong $Y$, Zhu F, et al:: Fenofibrate attenuated glucose-induced mesangial cells proliferation and extracellular matrix synthesis via PI3K/AKT and ERK1/2. PLoS One. 2013; 8(10): e76836.

PubMed Abstract | Publisher Full Text | Free Full Text

50. Song Q, Sun J, Wang J, et al.: Role of TRB3 in the inhibitory effect of fenofibrate against high glucose-induced proliferation of glomerular mesangial cells. Nan Fang Yi Ke Da Xue Xue Bao. 2013; 33(3): 391-6.

PubMed Abstract | Publisher Full Text

51. Selim E, Frkanec JT, Cunard R: Fibrates upregulates TRB3 in lymphocytes independent of PPAR alpha by augmenting CCAAT/enhancer binding protein beta (C/EBP beta) expression. Mol Immunol. 2007; 44(6): 1218-1229. PubMed Abstract | Publisher Full Text

52. Morse E, Selim E, Cunard R: PPARalpha ligands cause lymphocyte depletion and cell cycle block and this is associated with augmented TRB3 and reduced Cyclin B1 expression. Mol Immunol. 2009; 46(16): 3454-3461.

PubMed Abstract | Publisher Full Text

53. Ogata $\mathrm{T}$, Miyauchi $\mathrm{T}$, Irukayama-Tomobe $\mathrm{Y}$, et al:: The peroxisome proliferator-activated receptor alpha activator fenofibrate inhibits endothelin-1-induced cardiac fibroblast proliferation. J Cardiovasc Pharmacol. 2004; 44(Suppl 1): S279-82. PubMed Abstract

54. Irukayama-Tomobe $Y$, Miyauchi T, Sakai S, et al: Endothelin-1-induced cardiac hypertrophy is inhibited by activation of peroxisome proliferator-activated receptor-alpha partly via blockade of c-Jun NH2-terminal kinase pathway. Circulation. 2004; 109(7): 904-910.

PubMed Abstract | Publisher Full Text

55. Irukayama-Tomobe $Y$, Miyauchi $T$, Kasuya $Y$, et al: Activation of peroxisome proliferator-activated receptor-alpha decreases endothelin-1-induced p38 mitogen-activated protein kinase activation in cardiomyocytes. $J$ Cardiovasc Pharmacol. 2004; 44(Suppl 1): S358-61. PubMed Abstract | Publisher Full Text

56. Lee JK, Seo EM, Lee SS, et al:: Activation of PPARalpha Attenuates IFNgamma and IL-1beta-induced Cell Proliferation in Astrocytes: Involvement of IL-6 Independent Pathway. Korean J Physiol Pharmacol. 2010; 14(3): 185-9. PubMed Abstract | Publisher Full Text | Free Full Text

57. Thuillier $P$, Anchiraico GJ, Nickel KP et al: Activators of peroxisome proliferator-activated receptor-alpha partially inhibit mouse skin tumor promotion. Mol Carcinog. 2000; 29(3): 134-142. PubMed Abstract | Publisher Full Text

58. Gizard F, Amant C, Barbier O, et al.: PPAR alpha inhibits vascular smooth muscle cell proliferation underlying intimal hyperplasia by inducing the tumor suppressor p16 ${ }^{\text {INK4a }}$. J Clin Invest. 2005; 115(11): 3228-3238. PubMed Abstract | Publisher Full Text | Free Full Text

59. Saidi SA, Holland CM, Charnock-Jones DS, et al.: In vitro and in vivo effects of the PPAR-alpha agonist fenofibrate and retinoic acid in endometrial cancerMol Cancer. 2006; $5: 13$.

PubMed Abstract | Publisher Full Text | Free Full Text

60. Yokoyama $Y$, Xin B, Shigeto $T$, et al:: Clofibric acid, a peroxisome proliferatoractivated receptor alpha ligand, inhibits growth of human ovarian cancer. Mol Cancer Ther. 2007; 6(4): 1379-86. PubMed Abstract | Publisher Full Text

61. Yamasaki D, Kawabe N, Nakamura $\mathrm{H}$, et al.: Fenofibrate suppresses growth of the human hepatocellular carcinoma cell via PPAR $\alpha$-independent mechanisms. Eur J Cell Biol. 2011; 90(8): 657-64. PubMed Abstract | Publisher Full Text

62. Chang NW, Tsai MH, Lin C, et al.: Fenofibrate exhibits a high potential to suppress the formation of squamous cell carcinoma in an oral-specific4nitroquinoline1-oxide/arecoline mouse model. Biochim Biophys Acta. 2011; 1812(4): 558-64.

PubMed Abstract | Publisher Full Text

63. Huang J, Das SK, Jha P, et al.: The PPAR $\alpha$ agonist fenofibrate suppresses B-cell lymphoma in mice by modulating lipid metabolism. Biochim Biophys Acta. 2013; 1831(10): 1555-1565.

PubMed Abstract | Publisher Full Text

64. Wang $\mathrm{H}, \mathrm{He} \mathrm{CH}$, Bai LP, et al:: Effects of fenofibrate on the growth and migration of ovarian cancer cells in vitro. Sichuan Da Xue Xue Bao Yi Xue Ban. 2014; 45(5): 789-92. PubMed Abstract

65. Liang H, Kowalczyk P, Junco JJ, et al:: Differential effects on lung cancer cell proliferation by agonists of glucocorticoid and PPAR $\alpha$ receptors. Mol Carcinog. 2014; 53(9): 753-763. PubMed Abstract | Publisher Full Text

66. Zhang C, Beckermann B, Kallifatidis G, et al: Corticosteroids induce chemotherapy resistance in the majority of tumour cells from bone, brain, breast, cervix, melanoma and neuroblastoma. Int J Oncol. 2006; 29(5): 1295-1301.

PubMed Abstract | Publisher Full Text

67. Beg AA, Baltimore D: An essential role for NF-kappaB in preventing TNF alfainduced cell death. Science. 1996; 274(5288): 782-784.

PubMed Abstract | Publisher Full Text 
68. Antwerp DJV, Martin SJ, Kafri T, et al:: Suppression of TNF alfa induced apoptosis by NF-kappaB. Science. 1996; 274(5288): 787-789. PubMed Abstract | Publisher Full Text

69. Wang CY, Mayo MW, Baldwin AS Jr: TNF- and cancer therapy-induced apoptosis: potentiation by inhibition of NF-kappaB. Science. 1996; 274(5288): 784-787.

PubMed Abstract | Publisher Full Text

70. Baldwin AS: Control of oncogenesis and cancer therapy resistance by the transcription factor NF-KB. J Clin Invest. 2001; 107(3): 241-246. PubMed Abstract | Publisher Full Text | Free Full Text

71. Staels B, Koenig W, Habib A, et al:: Activation of human aortic smooth-muscle cells is inhibited by PPARalpha but not by PPARgamma activators. Nature. 1998; 393(6687): 790-3.

PubMed Abstract | Publisher Full Text

72. Xu X, Otsuki M, Saito H, et al:: PPARalpha and GR differentially down-regulate the expression of nuclear factor-kappaB-responsive genes in vascular endothelial cells. Endocrinology. 2001; 142(8): 3332-9.

PubMed Abstract | Publisher Full Text

73. Ogata T, Miyahuchi T, Sakai S, et al:: Myocardial fibrosis and diastolic dysfunction in deoxycorticosterone acetate-salt hypertensive rats is ameliorated by the peroxisome proliferator-activated receptor-alpha activator fenofibrate, partly by suppressing inflammatory responses associated with the nuclear factor-kappa-B pathway. J Am Coll Cardiol. 2004; 43(8): 1481-1488. PubMed Abstract | Publisher Full Text

74. Yang TL, Chen MF, Luo BL, et al: Fenofibrate decreases asymmetric dimethylarginine level in cultured endothelial cells by inhibiting NF-kappaB activity. Naunyn Schmiedebergs Arch Pharmacol. 2005; 371(5): 401-7. PubMed Abstract | Publisher Full Text

75. Xu J, Chavis JA, Racke MK, et al:: Peroxisome proliferator-activated receptoralpha and retinoid $X$ receptor agonists inhibit inflammatory responses of astrocytes. J Neuroimmunol. 2006; 176(1-2): 95-105. PubMed Abstract | Publisher Full Text

76. Li L, Emmett N, Mann D, et al:: Fenofibrate attenuates tubulointerstitial fibrosis and inflammation through suppression of nuclear factor- $\mathrm{\kappa} B$ and transforming growth factor- $\beta$ 1/Smad3 in diabetic nephropathy. Exp Biol Med (Maywood). 2010; 235(3): 383-91.

PubMed Abstract | Publisher Full Text | Free Full Text

77. Yang CS, Yuk JM, Kim JJ, et al.: Small heterodimer partner-targeting therapy inhibits systemic inflammatory responses through mitochondrial uncoupling protein 2. PLoS One. 2013; 8(5): e63435.

PubMed Abstract | Publisher Full Text | Free Full Text

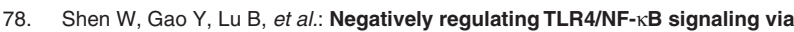
PPAR $\alpha$ in endotoxin-induced uveitis. Biochim Biophys Acta. 2014; 1842(7): 1109-20.

PubMed Abstract | Publisher Full Text

79. Binello $\mathrm{E}$, Germano IM: Targeting glioma stem cells: a novel framework for brain tumors. Cancer Sci. 2011; 102(11): 1958-66. PubMed Abstract | Publisher Full Text | Free Full Text

80. Grabacka M, Plonka PM, Urbanska K, et al.: Peroxisome proliferator-activated receptor alpha activation decreases metastatic potential of melanoma cells in vitro via down-regulation of Akt. Clin Cancer Res. 2006; 12(10): 3028-36. PubMed Abstract | Publisher Full Text

81. Li R, Zheng W, Pi R, et al:: Activation of peroxisome proliferator-activated receptor-alpha prevents glycogen synthase 3 beta phosphorylation and inhibits cardiac hypertrophy. FEBS Lett. 2007; 581(17): 3311-6. PubMed Abstract | Publisher Full Text

82. Kuno T, Hata K, Takamatsu M, et al.: The peroxisome proliferator-activated receptor (PPAR) $\alpha$ agonist fenofibrate suppresses chemically induced lung alveolar proliferative lesions in male obese hyperlipidemic mice. Int $J \mathrm{MOl} S \mathrm{Cl}$. 2014; 15(5): 9160-72.

PubMed Abstract | Publisher Full Text | Free Full Text

83. Piwowarczyk K, Wybieralska E, Baran J, et al.: Fenofibrate enhances barrier function of endothelial continuum within the metastatic niche of prostate cancer cells. Expert Opin Ther Targets. 2015; 19(2): 163-76. PubMed Abstract | Publisher Full Text

84. Keller BJ, Yamanaka H, Thurman RG: Inhibition of mitochondrial respiration and oxygen-dependent hepatotoxicity by six structurally dissimilar peroxisoma proliferating agents. Toxicology. 1992; 71(1-2): 49-61. PubMed Abstract | Publisher Full Text

85. Zhou Z, Wallace KB: The effect of peroxisome proliferators on mitochondrial bioenergetics. Toxicol Sci. 1999; 48(1): 82-89. PubMed Abstract | Publisher Full Text

86. Casas F, Pineau T, Rochard $P$, et al:: New molecular aspects of regulation of mitochondrial activity by fenofibrate and fasting. FEBS Lett. 2000; 482(1-2): $71-4$

PubMed Abstract | Publisher Full Text

87. Brunmair B, Lest A, Staniek K, et al:: Fenofibrate impairs rat mitochondrial function by inhibition of respiratory complex I. J Pharmacol Exp Ther. 2004; 311(1): 109-114.

PubMed Abstract | Publisher Full Text

88. Nadanaciva S, Dykens JA, Bernal A, et al: Mitochondrial impairment by PPAR agonists and statins identified via immunocaptured OXPHOS complex activities and respiration. Toxicol Appl Pharmacol. 2007; 223(3): 277-287. PubMed Abstract | Publisher Full Text
89. Wilk AM, Urbanska K, Impastato D, et al:: Abstract 3230: Fenofibrate mediated energy crisis and apoptotic cell death of glioglastoma. Cancer Res. 2012; 72: 3230.

Publisher Full Text

90. Ledesma A, de Lacoba MG, Rial E: The mitochondrial uncoupling proteins. Genome Biol. 2002; 3(12): REVIEWS3015. PubMed Abstract | Publisher Full Text | Free Full Text

91. Finck BN, Kelly DP: Peroxisome proliferator-activated receptor alpha (PPARalpha) signaling in the gene regulatory control of energy metabolism in the normal and diseased heart. J Mol Cell Cardiol. 2002; 34(10): 1249-57. PubMed Abstract | Publisher Full Text

92. Pecqueur C, Bui T, Gelly C, et al.: Uncoupling protein-2 controls proliferation by promoting fatty acid oxidation and limiting glycolysis-derived pyruvate utilization. FASEB J. 2008; 22(1): 9-18. PubMed Abstract | Publisher Full Tex

93. Grabacka M, Reiss K: Anticancer Properties of PPARalpha-Effects on Cellular Metabolism and Inflammation. PPAR Res. 2008; 2008: 9. PubMed Abstract | Publisher Full Text | Free Full Text

94. Srivastava RA, Jahagirdar R, Azhar S, et al:: Peroxisome proliferator-activated receptor-alpha selective ligand reduces adiposity, improves insulin sensitivity and inhibits atherosclerosis in LDL receptor-deficient mice. Mol Cell Biochem. 2006; 285(1-2): 35-50.

PubMed Abstract | Publisher Full Text

95. Baron A, Migita T, Tang D, et al:: Fatty acid synthase: a metabolic oncogene in prostate cancer? J Cell Biochem. 2004; 91(1): 47-53.

PubMed Abstract | Publisher Full Text

96. Hunt DA, Lane HM, Yygmont ME, et al.: MRNA stability and overexpression of fatty acid synthase in human breast cancer cell lines. Anticancer Res. 2007; 27(1A): 27-34 PubMed Abstract

97. Gansler TS, Hardman W 3rd, Hunt DA, et al.: Increased expression of fatty acid synthase (OA-519) in ovarian neoplasms predicts shorter survival. Hum Pathol. 1997; 28(6): 686-692.

PubMed Abstract | Publisher Full Text

98. Camassei FD, Cozza R, Acquaviva A, et al.: Expression of the lipogenic enzyme fatty acid synthase (FAS) in retinoblastoma and its correlation with tumor aggressiveness. Invest Ophthal Vis Sci. 2003; 44(6): 2399-2403. PubMed Abstract | Publisher Full Text

99. Ye Q, Chung LW, Li S, et al:: Identification of a novel FAS/ER-alpha fusion transcript expressed in human cancer cells. Biochim Biophys Acta. 2000; 1493(3): 373-377

PubMed Abstract | Publisher Full Text

100. Marchesi S, Lupattelli G, Lombardini R, et al:: Effects of fenofibrate on endothelial function and cell adhesion molecules during post-prandial lipemia in hypertriglyceridemia. J Clin Pharm Ther. 2003; 28(5): 419-424. PubMed Abstract | Publisher Full Text

101. Gervois P, Kleeman R, Pilon A, et al:: Global suppression of IL-6-induced acute phase response gene expression after chronic in vivo treatment with the peroxisome proliferator-activated receptor- $\alpha$ activator fenofibrate. $J$ Biol Chem. 2004; 279: 16154-16160

PubMed Abstract | Publisher Full Text

102. Lefebvre P, Chinetti G, Fruchart JC, et al.: Sorting out the roles of PPAR alpha in energy metabolism and vascular homeostasis. J Clin Invest. 2006; 116(3): 571-580.

PubMed Abstract | Publisher Full Text | Free Full Text

103. Ryan KE, McCance DR, Powell L, et al:: Fenofibrate and pioglitazone improve endothelial function and reduce arterial stiffness in obese glucose tolerant men. Atherosclerosis. 2007; 194(2): e123-30. PubMed Abstract | Publisher Full Text

104. Rosenson RS, Wolff DA, Huskin AL, et al.: Fenofibrate therapy ameliorates fasting and postprandial lipoproteinemia, oxidative stress, and the inflammatory response in subjects with hypertriglyceridemia and the metabolic syndrome. Diabetes Care. 2007; 30(8): 1945-51. PubMed Abstract | Publisher Full Text

105. Lee JW, Baiwa PJ, Carson MJ, et al.: Fenofibrate represses interleukin-17 and interferon-gamma expression and improves colitis in interleukin-10-deficient mice. Gastroenterology. 2007; 133(1): 108-123. PubMed Abstract | Publisher Full Text

106. Li $\mathrm{H}$, Cheng $X$, Yang $X$, et al.: The effects of fenobribate on ondothelial cell secretion of E selectin and ICAM-1. Jiangsu Medical Journal. 2007; 01. Reference Source

107. Samatov TR, Tonevitsky AG, Schumacher U: Epithelial-mesenchymal transition: focus on metastatic cascade, alternative splicing, non-coding RNAs and modulating compounds. Mol Cancer. 2013; 12: 107. PubMed Abstract | Publisher Full Text | Free Full Text

108. Wybieralska E, Szpak K, Górecki A, et al: Fenofibrate attenuates contactstimulated cell motility and gap junctional coupling in DU-145 human prostate cancer cell populations. Oncology Reports. 2011; 26.2: 447-453. PubMed Abstract | Publisher Full Text

109. Eberhart CE, Coffey RJ, Radhika A, et al.: Up-regulation of cyclooxygenase 2 gene expression in human colorectal adenomas and adenocarcinomas. Gastroenterology. 1994; 107(4): 1183-1188. PubMed Abstract 
110. Elder DJ, Baker JA, Banu NA, et al.: Human colorectal adenomas demonstrate a size dependent increase in epithelial cyclooxygenase-2 expression. J Pathol. 2002; 198(4): 428-434.

PubMed Abstract | Publisher Full Text

111. Castellone MD, Teramoto H, Williams BO, et al.: Prostaglandin E2 promotes colon cancer cell growth through a Gs-axin-beta-catenin signaling axis. Science. 2005; 310(5753): 1504-1510. PubMed Abstract | Publisher Full Text

112. Bocca $C$, levolella $M$, Autelli R, et al.: Expression of Cox-2 in human breast cancer cells as a critical determinant of epithelial-to-mesenchymal transition and invasiveness. Expert Opin Ther Targets. 2014; 18(2): 121-35. PubMed Abstract | Publisher Full Text

113. Kim HS, Moon HG, Han W, et al:: COX2 overexpression is a prognostic marker for Stage III breast cancer. Breast Cancer Res Treat. 2012; 132(1): 51-9. PubMed Abstract | Publisher Full Text

114. Singh B, Berry JA, Shoher A, et al.: COX-2 overexpression increases motility and invasion of breast cancer cells. Int J Oncol. 2005; 26(5): 1393-9. PubMed Abstract | Publisher Full Text

115. Simeone AM, Nieves-Alicea R, McMurtry VC, et al.: Cyclooxygenase-2 uses the protein kinase $\mathrm{C}$ / interleukin-8/urokinase-type plasminogen activator pathway to increase the invasiveness of breast cancer cells. Int J Oncol. 2007; 30(4): 785-92. PubMed Abstract | Publisher Full Text

116. Costa C, Soares R, Reis-Filho JS, et al.: Cyclo-oxygenase 2 expression is associated with angiogenesis and lymph node metastasis in human breast cancer. J Clin Pathol. 2002; 55: 429-434. PubMed Abstract | Publisher Full Text | Free Full Text

117. Soslow RA, Dannenberg AJ, Rush D, et al:: COX-2 is expressed in human pulmonary, colonic, and mammary tumors. Cancer. 2000; 89: 2637-2645. PubMed Abstract | Publisher Full Text

118. Wang ZM, Liu J, Liu HB, et al:: Abnormal COX2 protein expression may be correlated with poor prognosis in oral cancer: a meta-analysis. Biomed Res Int. 2014; 2014: 364207.

PubMed Abstract | Publisher Full Text | Free Full Text

119. Spano JP, Chouahnia K, Morère JF, et al:: Cyclooxygenase 2 inhibitors and lung carcinoma. Bull Cancer. 2004; 91(Suppl 2): S109-12. PubMed Abstract

120. Konturek PC, Nikiforuk A, Kania J, et al.: Activation of NFkappaB represents the central event in the neoplastic progression associated with Barrett's esophagus: a possible link to the inflammation and overexpression of COX-2, PPARgamma and growth factors. Dig Dis Sci. 2004; 49(7-8): 1075-83. PubMed Abstract | Publisher Full Text

121. Chen XR, Besson VC, Palmier B, et al.: Neurological recovery-promoting, antiinflammatory, and anti-oxidative effects afforded by fenofibrate, a PPAR alpha agonist, in traumatic brain injury. $J$ Neurotrauma. 2007; 24(7): 1119-31. PubMed Abstract | Publisher Full Text

122. Chen YJ, Quilley J: Fenofibrate treatment of diabetic rats reduces nitrosative stress, renal cyclooxygenase-2 expression, and enhanced renal prostaglandin release. J Pharmacol Exp Ther. 2008; 324(2): 658-63. PubMed Abstract | Publisher Full Text

123. Lee DL, Wilson JL, Duan R, et al.: Peroxisome Proliferator-Activated Receptor- $\alpha$ Activation Decreases Mean Arterial Pressure, Plasma Interleukin-6, and COX-2 While Increasing Renal CYP4A Expression in an Acute Model of DOCA-Salt Hypertension. PPAR Res. 2011; 2011: 502631. PubMed Abstract | Publisher Full Text | Free Full Text

124. Alvarez de Sotomayor dM, Mingorance C, Andriantsitohaina R: Fenofibrate improves age-related endothelial dysfunction in rat resistance arteries. Atherosclerosis. 2007; 193(1): 112-120. PubMed Abstract | Publisher Full Text

125. Ramanan S, Kooshki M, Zhao W, et al:: PPARalpha ligands inhibit radiationinduced microglial inflammatory responses by negatively regulating NFkappaB and AP-1 pathways. Free Radic Biol Med. 2008; 45(12): 1695-1704 PubMed Abstract | Publisher Full Text | Free Full Text

126. Urbanska K, Pannizzo P, Grabacka M, et al.: Activation of PPARalpha inhibits IGF-I-mediated growth and survival responses in medulloblastoma cell lines. Int J Cancer. 2008; 123(5): 1015-24. PubMed Abstract | Publisher Full Text | Free Full Text

127. Drukala J, Urbanska K, Wilk A, et al.: ROS accumulation and IGF-IR inhibition contribute to fenofibrate/PPARalpha -mediated inhibition of glioma cell motility in vitro. Molecular Cancer. 2010; 9: 159. PubMed Abstract | Publisher Full Text | Free Full Text

128. Trojan J, Cloix JF, Ardourel MY, et al.: Insulin-like growth factor type I biology and targeting in malignant gliomas. Neuroscience. 2007; 145(3): 795-811. PubMed Abstract | Publisher Full Tex

129. D'Ambrosio C, Ferber A, Resnicoff M, et al.: A soluble insulin-like growth factor I receptor that induces apoptosis of tumor cells in vivo and inhibits tumorigenesis. Cancer Res. 1996; 56(17): 4013-4020. PubMed Abstract

130. Toda K, Okada T, Miyaura C, et al.: Fenofibrate, a ligand for PPARalpha, inhibits aromatase cytochrome P450 expression in the ovary of mouse. J Lipid Res. 2003; 44(2): 265-270.

PubMed Abstract | Publisher Full Text
131. Zhao H, Zhu C, Qin C, et al.: Fenofibrate down-regulates the expressions of androgen receptor (AR) and AR target genes and induces oxidative stress in the prostate cancer cell line LNCaP. Biochem Biophys Res Commun. 2013; 432(2): 320-5

PubMed Abstract | Publisher Full Text

132. Liu X, Jang SS, An Z, et al.: Fenofibrate decreases radiation sensitivity via peroxisome proliferator-activated receptor $\alpha$-mediated superoxide dismutase nduction in HeLa cells. Radiat Oncol J. 2012; 30(2): 88-95. PubMed Abstract | Publisher Full Text | Free Full Text

133. Ge Y, Liu J, Yang X, et al.: Fenofibrate enhances radiosensitivity of esophageal squamous cell carcinoma by suppressing hypoxia inducible factor-10 expression. Tumour Biol. 2014; 35(11): 10765-10771. PubMed Abstract | Publisher Full Text

134. Liu J, Ge YY, Zhu HC, et al.: Fenofibrate increases radiosensitivity in head and neck squamous cell carcinoma via inducing G2/M arrest and apoptosis. Asian Pac J Cancer Prev. 2014; 15(16): 6649-6655.

PubMed Abstract | Publisher Full Text

135. Collet $\mathrm{P}$, Domenjoud $\mathrm{L}$, Devignes MD, et al:: The human semaphorin $6 \mathrm{~B}$ gene is down regulated by PPARs. Genomics. 2004; 83(6): 1141-50. PubMed Abstract | Publisher Full Text

136. Murad $\mathrm{H}$, Collet $\mathrm{P}$, Huin-Schohn $\mathrm{C}$, et al.: Effects of PPAR and RXR ligands in semaphorin 6B gene expression of human MCF-7 breast cancer cells. Int J Oncol. 2006; 28(4): 977-84. PubMed Abstract | Publisher Full Text

137. $\mathrm{Ge} \mathrm{C}, \mathrm{Li} \mathrm{Q}$, Wang $\mathrm{L}$, et al.: The role of axon guidance factor semaphorin $6 \mathrm{~B}$ in the invasion and metastasis of gastric cancer. J Int Med Res. 2013; 41(2): 284-92.

PubMed Abstract | Publisher Full Text

138. Correa RG, Sasahara RM, Bengtson MH, et al: Human semaphorin $6 \mathrm{~B}$ [(HSA)SEMA6B], a novel human class 6 semaphorin gene: alternative splicing and all-trans-retinoic acid-dependent downregulation in glioblastoma cell lines. Genomics. 2001; 73(3): 343-8. PubMed Abstract | Publisher Full Text

139. Murakami $\mathrm{H}$, Murakami $\mathrm{R}$, Kambe $\mathrm{F}$, et al.: Fenofibrate activates AMPK and increases eNOS phosphorylation in HUVEC. Biochem Biophys Res Commun. 2006; 341(4): 973-978.

PubMed Abstract | Publisher Full Text

140. Jiying W, Tao W, Jinrong Z, et al.: Effect of combined arsenic trioxide and fenofibrate on epithelial-interstitial transformation and E-cadherin/snail transformation factor in human pulmonary carcinoma A $\mathbf{5 4 9}$ cells. Journal of Third Military University. 2012-14. Reference Source

141. Tanaka T, Kohno H, Yoshitani S, et al.: Ligands for peroxisome proliferatoractivated receptors alpha and gamma inhibit chemically induced colitis and formation of aberrant crypt foci in rats. Cancer Res. 2001; 61(6): 2424-2428. PubMed Abstract

142. Murtola TJ, Tammela TL, Lahtela J, et al.: Cholesterol-lowering drugs and prostate cancer risk: a population-based case-control study. Cancer Epidemiol Biomarkers Prev. 2007; 16(11): 2226-32. PubMed Abstract | Publisher Full Text

143. Rao A, D'Amico S, Balasubramanyam A, et al:: Fenofibrate is effective in treating hypertriglyceridemia associated with HIV lipodystrophy. Am J Med Sci. 2004; 327(6): 315-8.

PubMed Abstract | Publisher Full Text

144. Koltai T: Nelfinavir and other protease inhibitors in cancer: mechanisms involved in anticancer activity. F1000Res. 2015; 4: 9. Publisher Full Text

145. Bonnet E, Ruidavets JB, Tuech J, et al.: Apoprotein c-III and E-containing lipoparticles are markedly increased in HIV-infected patients treated with protease inhibitors: association with the development of lipodystrophy. J Clin Endocrinol Metab. 2001; 86(1): 296-302. PubMed Abstract | Publisher Full Text

146. Samson SL, Pownall HJ, Scott LW, et al.: Heart positive: design of a randomized controlled clinical trial of intensive lifestyle intervention, niacin and fenofibrate for HIV lipodystrophy/dyslipidemia. Contemp Clin Trials. 2006; 27(6): 518-30.

PubMed Abstract | Publisher Full Text

147. Thomas JC, Lopes-Virella MF, Bene VE, et al.: Use of fenofibrate in the management of protease inhibitor-associated lipid abnormalities. Pharmacotherapy. 2000; 20(6): 727-734. PubMed Abstract | Publisher Full Text

148. Collett GP, Betts AM, Johnson MI, et al.: Peroxisome proliferator-activated receptor alpha is an androgen-responsive gene in human prostate and is highly expressed in prostatic adenocarcinoma. Clin Cancer Res. 2000; 6(8): 3241-8. PubMed Abstract

149. Fauconnet S, Lascombe I, Chabannes E, et al:: Differential regulation of vascular endothelial growth factor expression by peroxisome proliferator-activated receptors in bladder cancer cells. J Biol Chem. 2002; 277(26): 23534-43. PubMed Abstract | Publisher Full Text

150. Suchanek KM, May F, Robinson JA, et al.: Peroxisome proliferator-activated receptor alpha in the human breast cancer cell lines MCF-7 and MDA-MB-231. Mol Carcinog. 2002; 34(4): 165-171. PubMed Abstract | Publisher Full Text 
151. Jackson L, Wahli W, Michalik L, et al.: Potential role for peroxisome proliferator activated receptor (PPAR) in preventing colon cancer. Gut. 2003; 52(9): 1317-1322.

PubMed Abstract | Publisher Full Text | Free Full Text

152. Li MY, Yuan H, Ma LT, et al.: Roles of peroxisome proliferator-activated receptor-alpha and -gamma in the development of non-small cell lung cancer Am J Respir Cell Mol Biol. 2010; 43(6): 674-83.

PubMed Abstract | Publisher Full Text

153. Palmer $\mathrm{CN}$, Hsu MH, Griffin KJ, et al:: Peroxisome proliferator activated receptoralpha expression in human liver. Mol Pharmacol. 1998; 53(1): 14-22. PubMed Abstract

154. Roberts RA, James NH, Hasmall SC, et al:: Apoptosis and proliferation in nongenotoxic carcinogenesis: species differences and role of PPARalpha. Toxicol Lett. 2000; 112-113: 49-57. PubMed Abstract | Publisher Full Text

155. Vanden Heuvel JP, Kreder D, Belda B, et al.: Comprehensive analysis of gene expression in rat and human hepatoma cells exposed to the peroxisome proliferator WY14,643. Toxicol Appl Pharmacol. 2003; 188(3): 185-98. PubMed Abstract | Publisher Full Text

156. Rao MS, Reddy JK: Peroxisome proliferation and hepatocarcinogenesis. Carcinogenesis. 1987; 8(5): 631-636. PubMed Abstract | Publisher Full Text

157. Wilk A, Urbanska K, Grabacka M, et al.: Fenofibrate-induced nuclear translocation of FoxO3A triggers Bim-mediated apoptosis in glioblastoma cells in vitro. Cell Cycle. 2012; 11(14): 2660-2671. PubMed Abstract | Publisher Full Text | Free Full Text

158. Wilk A, Wyczechowska D, Zapata A, et al:: Molecular mechanisms of fenofibrateinduced metabolic catastrophe and glioblastoma cell death. Mol Cell Biol. 2005; 35(1): 182-198.

PubMed Abstract | Publisher Full Text | Free Full Text

159. Han DF, Zhang J, Wei W, et al.: Fenofibrate induces $G_{0} / G_{1}$ phase arrest by modulating the PPAR $\alpha /$ Fox01/p27 $7^{\text {kip }}$ pathway in human glioblastoma cells. Tumor Biol. 2015.

PubMed Abstract | Publisher Full Text

160. Tsao SC, Tsai MH, Chiu CF, et al:: AMPK-dependent signaling modulates the suppression of invasion and migration by fenofibrate in CAL 27 oral cancer through NF-kB pathway. Environ Toxicol. 2014; PubMed Abstract | Publisher Full Text

161. Grau R, Punzón C, Fresno M, et al.: Peroxisome-proliferator-activated receptor alpha agonists inhibit cyclo-oxygenase 2 and vascular endothelial growth factor transcriptional activation in human colorectal carcinoma cells via inhibition of activator protein-1. Biochem J. 2006; 395(1): 81-88. PubMed Abstract | Publisher Full Text | Free Full Text

162. Vamecq J, Colet JM, Vanden Eynde JJ, et al.: PPARs: interference with Warburg' effect and clinical anticancer trials. PPAR Res. 2012; 2012: 304760. PubMed Abstract | Publisher Full Text | Free Full Text

163. Sekiya M, Yahagi N, Matsuzaka T, et al.: Polyunsaturated fatty acids ameliorate hepatic steatosis in obese mice by SREBP-1 suppression. Hepatology. 2003; 38(6): 1529-1539.

PubMed Abstract | Publisher Full Text

164. Kim HJ, Takahashi M, Ezaki O: Fish Oil Feeding Decreases Mature Sterol Regulatory Element-binding Protein 1 (SREBP-1) by Down-regulation of SREBP-1c mRNA in Mouse Liver A POSSIBLE MECHANISM FOR DOWNREGULATION OF LIPOGENIC ENZYME mRNAs. J Biol Chem. 1999; 274(36): 25892-25898.

PubMed Abstract | Publisher Full Text

165. Guo K, Wang PR, Milot DP, et al:: Regulation of lipid metabolism and gene expression by fenofibrate in hamsters. Biochim Biophys Acta. 2001; 1533(3): 220-232. PubMed Abstract | Publisher Full Text

166. König B, Koch A, Spielmann J, et al: Activation of PPARalpha lowers synthesis and concentration of cholesterol by reduction of nuclear SREBP-2. Biochem Pharmacol. 2007; 73(4): 574-585.

PubMed Abstract | Publisher Full Text 


\section{Open Peer Review}

\section{Current Peer Review Status: ?}

\section{Version 1}

Reviewer Report 11 May 2015

https://doi.org/10.5256/f1000research.6595.r8393

(C) 2015 Reiss K. This is an open access peer review report distributed under the terms of the Creative Commons Attribution License, which permits unrestricted use, distribution, and reproduction in any medium, provided the original work is properly cited.

\section{Krzysztof Reiss}

Stanley S Scott Cancer Center, Louisiana State University Health Sciences Center, New Orleans, LA, USA

This in an excellent comprehensive review of the literature related to Fenofibrate anticancer effects, which definitely deserves to be indexed after revision.

I have three comments which should be implemented:

1. It should be mentioned that fenofibrate is a prodrug, which is processed by blood esterases to fenofibric acid, and that fenofibric acid is potent agonist of PPARa. Therefore, there are two very different substances, fenofibrate and fenofibric acid, which could have very different anticancer properties. As far as I understand the system, mitochondrial and growth factor-mediated effects are rather associated with unprocessed fenofibrate, which in opposite to fenofibric acid is capably of interacting with biological membranes.

2. Reference 89 in table 6 should be updated (see below); and the issue of Fenofibrate and mitochondrial respiration deserves a separate paragraph since it explains how unprocessed fenofibrate can target tumor cells, being at the same time much less harmful to normal cells. Other described mechanisms could be involved as a consequence of this primary mitochondrial action, which actually happens in minutes.

Wilk A, Wyczechowska D, Zapata A, Dean M, Mullinax J, Marrero L, Parsons C, Peruzzi F, Culicchia F, Ochoa A, Grabacka M, Reiss K. Molecular mechanisms of fenofibrate-induced metabolic catastrophe and glioblastoma cell death. Mol Cell Biol. 2015 Jan;35(1):182-98. doi: 10.1128/MCB.00562-14. Epub 2014 Oct 20. PubMed PMID: 25332241; PubMed Central PMCID: PMC4295376.

3. Reference 158 has a mistake it should be MCB 2015 instead of MCB 2005

Competing Interests: No competing interests were disclosed. 


\section{I confirm that I have read this submission and believe that I have an appropriate level of expertise to confirm that it is of an acceptable scientific standard, however I have significant reservations, as outlined above.}

\section{Author Response 13 May 2015}

Tomas Koltai, Centro de Diagnostico y Tratamiento de la Obra Social del Personal de la Alimentación, Buenos Aires, Argentina

Dear Dr. Krzysztof Reiss

Thank you for your kind contribution to this review.

A new version is under way, which will include all the issues you remarked:

1. A figure will be introduced which will show the molecular structure of FF and fibric acid. The difference between the pharmacologic actions of both will be discussed.

2. Membrane rigidity due to FF will be explained under a new heading and the importance of this effect will be further discussed. The difference in cell distribution of FA and FF will be also considered.

3. Reference in Table 6 will be updated and reference 158 will be corrected.

Remains sincerely yours

Tomas Koltai

Competing Interests: There are no conflicts of interests

The benefits of publishing with F1000Research:

- Your article is published within days, with no editorial bias

- You can publish traditional articles, null/negative results, case reports, data notes and more

- The peer review process is transparent and collaborative

- Your article is indexed in PubMed after passing peer review

- Dedicated customer support at every stage

For pre-submission enquiries, contact research@f1000.com 